\title{
Organosilicon polymer-derived ceramics: An overview
}

\author{
Shengyang FU, Min ZHU*, Yufang ZHU* \\ School of Materials Science and Engineering, University of Shanghai for \\ Science and Technology, Shanghai 200093, China
}

Received: January 4, 2019; Revised: April 22, 2019; Accepted: April 22, 2019

(c) The Author(s) 2019.

\begin{abstract}
Polymer-derived ceramics (PDCs) strategy shows a great deal of advantages for the fabrication of advanced ceramics. Organosilicon polymers facilitate the shaping process and different silicon-based ceramics with controllable components can be fabricated by modifying organosilicon polymers or adding fillers. It is worth noting that silicate ceramics can also be fabricated from organosilicon polymers by the introduction of active fillers, which could react with the produced silica during pyrolysis. The organosilicon polymer-derived ceramics show many unique properties, which have attracted many attentions in various fields. This review summarizes the typical organosilicon polymers and the processing of organosilicon polymers to fabricate silicon-based ceramics, especially highlights the three-dimensional (3D) printing technique for shaping the organosilicon polymerderived ceramics, which makes the possibility to fabricate silicon-based ceramics with complex structure. More importantly, the recent studies on fabricating typical non-oxide and silicate ceramics derived from organosilicon polymers and their biomedical applications are highlighted.
\end{abstract}

Keywords: polymer-derived ceramics (PDCs); organosilicon polymers; 3D printing; silicon-based ceramics

\section{Introduction}

Silicon-based ceramics including non-oxide ceramics, such as silicon carbide $(\mathrm{SiC})[1-3]$, silicon oxycarbide (SiOC) [4,5], silicon nitride $\left(\mathrm{Si}_{3} \mathrm{~N}_{4}\right)$ [6-8], and their derivatives ( $\mathrm{SiCN}, \mathrm{SiAlON}$, etc.) $[9,10]$ are being utilized in a wide range of applications owing to their heat resistance, chemical stability, excellent mechanical properties or electric properties, etc. On the other hand, as another type of silicon-based ceramics, silicate ceramics also have been applied as dielectric ceramics [11] and bioceramics [12,13]. A variety of studies have demonstrated the fabrication processes of silicon-based

* Corresponding authors.

E-mail: M. Zhu,mzhu@usst.edu.cn;

Y.Zhu, yfzhu@usst.edu.cn ceramics including the preparation of raw materials, shaping, porosity making as well as sintering. However, traditional fabrication methods to silicon-based ceramics including solid state reaction and sol-gel method, are either high-energy consumption or difficult in processing and shaping. For instance, industrial $\mathrm{SiC}$ is fabricated by the solid state reaction between petroleum coke and $\mathrm{SiO}_{2}$ at $2000{ }^{\circ} \mathrm{C}$ [2]. Silicon powder reacts with $\mathrm{N}_{2}$ to form $\alpha-\mathrm{Si}_{3} \mathrm{~N}_{4}$ and $\beta-\mathrm{Si}_{3} \mathrm{~N}_{4}$ under a reducing atmosphere beyond $1400{ }^{\circ} \mathrm{C}$ [14]. Sol-gel method decreases the energy consumption, but still does not facilitate the shaping process [15].

Organosilicon polymers have been successfully synthesized and used to fabricate silicon-based ceramics for more than 45 years [16-20]. Generally, the fabrication of organosilicon polymer-derived silicon-based ceramics involves the cross-linking, pyrolysis, and ceramization 
of the organosilicon polymers. In the early 1970s, $\mathrm{Si}_{3} \mathrm{~N}_{4} / \mathrm{SiC}$ ceramic fibers were successfully synthesized from the organosilicon polymers by Fritz and Verbeek et al. for the first time [21]. To date, except for binary silicon-based ceramics $\left(\mathrm{SiC}, \mathrm{Si}_{3} \mathrm{~N}_{4}\right)$, ternary silicon-based ceramics including $\mathrm{SiCN}, \mathrm{SiOC}$ as well as silicate ceramics have been derived from the organosilicon polymers [22]. Interestingly, the organosilicon polymers are able to act as silicon sources, which can react with active fillers to form silicate ceramics during pyrolysis. One of the most important advantages for organosilicon polymer-derived ceramics strategy is the possibility of combining the free shaping and synthesis of raw materials. On the other hand, the dispersity of fillers is much better in organosilicon polymer solution than that in solid systems, which benefits for diffusion and thereby reduces the reaction activation energy, resulting in the decrease of sintering temperature.

This review summarizes the most commonly used organosilicon polymers for the fabrication of siliconbased ceramics and introduces their different synthesis methods briefly. To fabricate final silicon-based ceramics, shaping, cross-linking, pyrolysis, and ceramization of organosilicon polymers are also indispensable processes, so their influences on the final ceramics will be discussed. As an advanced shaping method, three-dimensional (3D) printing technique has been developed rapidly [23-26], which will be highlighted in the field of fabricating organosilicon polymer-derived silicon-based ceramics. Finally, different types of organosilicon polymer-derived silicon-based ceramics, including binary, ternary non-oxide silicon-based ceramics as well as silicate ceramics will be reviewed in detail. Moreover, the biomedical applications of these silicon-based ceramics will be introduced and forecasted.

\section{Organosilicon polymers}

Synthesis of organosilicon polymers is the first key issue for fabricating silicon-based ceramics, which greatly influences the final ceramic compositions, and therefore determines the ceramics' properties. To fabricate silicon-based ceramics, the organosilicon polymers should possess a high molecular weight, appropriate solubility for shaping, and the ability for cross-linking. Different elements, such as silicon, carbon, nitrogen, and oxygen, are grafted to the silicon atoms on the backbone structure for the formation of different organosilicon polymers, such as polysilane, polycarbosilane, polysilazane, and polysiloxane. Also, the side chain groups grafted to silicon atoms and the molecular structure of the organosilicon polymers are important factors on final ceramics, which are related to the decomposition properties of organosilicon polymers. Here, organosilicon polymers are mainly divided into polysilane, polycarbosilane, polysilazane, polysiloxane, and their backbone structures, synthesis methods, and applications are summarized in Table 1.

Table 1 A summary of the backbone structure, synthesis methods, and applications for the common organosilicon polymers

\begin{tabular}{|c|c|c|c|c|}
\hline Organosilicon polymer & Backbone structure & Synthesis methods & Applications & Reference \\
\hline Polysilane & $-\mathrm{R}_{1} \mathrm{R}_{2} \mathrm{Si}-$ & $\begin{array}{l}\text { Wurtz-type coupling of halosilanes } \\
\text { Anionic polymerization of masked disilenes } \\
\text { Catalytic dehydrogenation of silanes } \\
\text { Reduction of dichlorosilanes }\end{array}$ & $\begin{array}{c}\text { Photoresists } \\
\text { Photo conductors } \\
\text { Semiconductors } \\
\text { Precursors for synthesis of polycarbosilane }\end{array}$ & [27-29] \\
\hline Polycarbosilane & $-\mathrm{R}_{1} \mathrm{R}_{2} \mathrm{Si}-\mathrm{C}-$ & $\begin{array}{l}\text { Kumada rearrangement of polysilanes } \\
\text { Ring opening polymerization } \\
\text { Dehydrocoupling reaction of trimethylsilane } \\
\text { Hydrosilylation of vinylhydridosilanes } \\
\text { Grignard coupling reaction of (chloromethyl)- } \\
\text { triethoxysilane and vinylmagnesium bromide }\end{array}$ & $\begin{array}{c}\text { Precursors for preparation of } \mathrm{SiC} \\
\text { Electric or photo conductors } \\
\text { Photoresist } \\
\text { Nonlinear optical materials }\end{array}$ & $\begin{array}{l}{[30,31} \\
33,34]\end{array}$ \\
\hline Polysilazane & $-\mathrm{R}_{1} \mathrm{R}_{2} \mathrm{Si}-\mathrm{N}=$ & $\begin{array}{c}\text { Ammonolysis reactions of chlorosilanes with } \\
\text { ammonia or by aminolysis } \\
\text { Ring opening polymerization of } \\
\text { cyclic polysilanane }\end{array}$ & $\begin{array}{l}\text { Precursors for preparation } \\
\text { of } \mathrm{Si}_{3} \mathrm{~N}_{4} \text { or } \mathrm{SiCN} \\
\text { Barrier for heat exchanger or } \\
\text { on steel against oxidation }\end{array}$ & {$[47]$} \\
\hline Polysiloxane & $-\mathrm{R}_{1} \mathrm{R}_{2} \mathrm{Si}-\mathrm{O}-$ & $\begin{array}{l}\text { Ring-open polymerization of cyclic silaethers } \\
\text { Polycondensation of linear silanes }\end{array}$ & $\begin{array}{c}\text { Precursors for preparation of SiOC } \\
\text { Medicine } \\
\text { Electronics } \\
\text { Textile chemistry }\end{array}$ & $\begin{array}{c}{[21,23,52,} \\
55,56]\end{array}$ \\
\hline Polysilylcarbodiimides & $-\mathrm{R}_{1} \mathrm{R}_{2} \mathrm{Si}-\mathrm{N}=\mathrm{C}=\mathrm{N}-$ & $\begin{array}{l}\text { Pyridine-catalyzed polycondensation reaction of } \\
\text { chlorosilanes with bis(trimethylsilylcarbodiimide) }\end{array}$ & Precursors for preparation of $\mathrm{SiCN}$ & {$[59]$} \\
\hline Polyborosilazane & $-\mathrm{R}_{1} \mathrm{R}_{2} \mathrm{Si}-\mathrm{N}\left(\mathrm{R}_{3} \mathrm{R}_{4} \mathrm{~B}\right)-$ & $\begin{array}{l}\text { Co-condensation reaction of boron trichloride, } \\
\text { organodichlorosilanes, and hexamethyldisilazane }\end{array}$ & Precursors for preparation of $\mathrm{SiCBN}$ & {$[65]$} \\
\hline
\end{tabular}




\section{1 Polysilane}

Polysilane is a kind of polymer with a simple one-dimensional silicon backbone. Its $\sigma$ conjugation is formed owing to the delocalization of electrons on silicon-silicon bonds, which endows itself with special optoelectronic and photoelectric properties for potential applications in photoresists, photoconductors, and semiconductors. The side chain groups and molecular weight of polysilane are two main factors that influence its properties.

Conventional Wurtz-type coupling of halosilanes is the most common synthetic method to synthesize the homopolymeric or copolymeric polysilane. In this method, chlorosilanes react with sodium or lithium dispersion and are reduced to form polysilane in a high boiling point inert solvent (toluene, benzene, or tetrahydrofurane) under reflux. Other methods include the anionic polymerization of masked disilenes, the anionic ring-opening polymerization, the catalytic dehydrogenation of silanes, and the reduction of dichlorosilanes with magnesium $(\mathrm{Mg})$ in the presence of Lewis acid and $\mathrm{LiCl}[27,28]$. However, these methods often suffer from some limitations owing to the instability under the light or moisture condition that cause the difficulty for controlled synthesis [29].

As a preceramic polymer, polysilane has been first reported that polydimethylsilane could be pyrolyzed to form $\mathrm{SiC}$ fiber at $1100-1300{ }^{\circ} \mathrm{C}$ in 1975 [23]. During the heating treatment, polydimethlysliane can convert to be polycarbosilane at about $400{ }^{\circ} \mathrm{C}$, which is called Kumada rearrangement. To take full advantage of it, many studies focused on the synthesis of polycarbosilane from polydimethylsilane to fabricate high-performance $\mathrm{SiC}$ ceramics as well [30-32].

\section{2 Polycarbosilane}

The structures of polycarbosilane are complex due to the different forms of carbon chains in the backbone, such as methylene, vinylidene, phenylene, etc. So some kinds of polycarbosilanes possess an alternating arrangement of a $\pi$-conjugated unit, which is called unsaturated polycarbosilane.

There are several methods to synthesize polycarbosilane, and the aforementioned Kumada rearrangement of polysilanes is most commonly used that can be carried out under either high pressure or atmospheric pressure condition [30,31,33]. Other methods include ring-opening polymerization, dehydrocoupling reaction of trimethylsilane, hydrosilylation of vinylhydridosilanes, and the Grignard coupling reaction of (chloromethyl)triethoxysilane and vinylmagnesium bromide [34].

To date, polycarbosilane has also been widely used for electric or photo conductor, photoresist, and nonlinear optical materials, as well as preceramic precursors for fabricating $\mathrm{SiC}$ fiber, powder, whiskers, composites, and nanomaterials [35-38]. To investigate its relationships and differences with polysilane for fabricating $\mathrm{SiC}$ ceramics, a comparative study on the thermal behavior of some polysilanes and polycarbosilanes was carried out by Shukla et al. [39]. It was found that polydimethylsilane (PDMS) and polydimethylmethylphenylsilane (PDMMPS) were suitable for synthesizing polycarbosilane by Kumada rearrangement. However, polydimethyl-methylsilane (PDMMS) could produce $\mathrm{SiC}$ directly, instead of synthesizing polycarbosilane due to its great cross-linking ability under heat treatments. For polycarbosilanes, the carbon yield increased with the increase of molecular weight, which greatly influences the quality of $\mathrm{SiC}$ ceramics [39].

\section{3 Polysilazane}

Polysilazane polymers, whose backbones consist of alternating silicon-nitrogen bonds with carbon-containing side groups, are always used as the precursors for fabricating SiCN ceramics [40-42]. The bond energy of silicon-nitrogen (ca. $360 \mathrm{~kJ} / \mathrm{mol}$ ) is smaller than that of silicon-oxygen and silicon-carbon, which makes the bond easily transform into other bonds in some chemical reactions, and thereby benefits for the formation of new compounds under certain conditions. In addition, polysilazane provides high thermal stability, oxidation resistance, and corrosion resistance, thus promoting its wide use as the barrier for heat exchanger or on steel against oxidation [43-46].

The reactions between chlorosilane and amine, as well as between silazane and butyllithium are two most popular strategies for synthesizing small-molecular silazane. So polysilazane can be synthesized by ammonolysis reactions of chlorosilanes with ammonia or by aminolysis. On the other hand, the ring-opening polymerization of cyclic polysilanane is another efficient method to synthesize polysilazane [47].

In the 1970s, Verbeek et al. reported the fabrication of $\mathrm{SiCN}$ ceramic fibers by melt-spinning from polycarbosilazanes for the first time, and the $\mathrm{SiCN}$ 
ceramic fibers exhibited superior strength and elastic modulus compared to the $\mathrm{SiC}$ fibers. Also, the fabricated $\mathrm{SiCN}$ ceramic fibers showed excellent oxidation resistance up to $1200{ }^{\circ} \mathrm{C}[47,48]$. As a carbon-free polysilazane, perhydridopolysilazane can be used as the precursor for fabricating $\mathrm{Si}_{3} \mathrm{~N}_{4}$ ceramics [49]. Importantly, depending on the processing conditions of polysilazane, the ceramic compositions can change from binary $(\mathrm{Si} / \mathrm{N})$ to ternary $(\mathrm{Si} / \mathrm{C} / \mathrm{N})$ ceramics or quaternary systems.

\section{4 Polysiloxane}

Polysiloxane or silicone has been known for a long time and been used in industry as preceramic polymers, medicine, electronics, textile chemistry, etc. [50-52]. The low inter-molecular force of the silicon-oxygen-silicon backbone in polysiloxane makes the polymer flexible, resulting in low glass transition temperature. Besides, polysiloxane shows good resistance to high temperature or ozone, low surface tension and energy, as well as high gas permeability $[53,54]$.

Two general methods including the ring-opening polymerization of cyclic silaethers and the polycondensation of linear silanes terminated with active functional groups have been developed to synthesize polysiloxane [21]. Dimethyl-dichloro silane is often used for the industrial synthesis of polysiloxanes [23]. In general, cross-linked polysiloxane is able to achieve a higher ceramic yield. The highly cross-linked polysiloxane can be synthesized through the modification of thermal or irradiation-sensitive curing chain groups [52,55] or through a sol-gel method by hydrolysis and condensation of hybrid silicon alkoxides [56]. The sol-gel method allows for controlling compositions and introducing additional elements within the preceramic network by using metal alkoxides. With the exception of SiOC-based ceramics, silicate ceramics can be fabricated from polysiloxane by adding active fillers. As a silicon source, polysiloxane reacts with active fillers to form a desired ceramic phase at a proper temperature [18].

\section{5 Other organosilicon polymers}

In addition to the above common organosilicon polymers, many other organosilicon polymers have been developed and synthesized. For example, polysilylcarbodiimides, of which the general formula is $-\left[\mathrm{R}_{1} \mathrm{R}_{2} \mathrm{Si}-\mathrm{X}\right]_{n}-$, where $\mathrm{X}$ is $\mathrm{N}=\mathrm{C}=\mathrm{N}$ and $\mathrm{R}$ groups can be hydrogen, phenyl, methyl, ethyl, and others, are preceramic precursors for fabricating SiCN-based ceramics [57,58]. Polysilylcarbodiimides are moisture sensitive, and can be synthesized by the pyridine-catalyzed polycondensation reaction of chlorosilanes with bis(trimethylsilylcarbodiimide) [59]. As another type of SiOC-based ceramic precursors, the hyperbranched-polycarbosiloxanes have been reported to improve ceramic yields [60-62]. Boron-containing organosilicon polymers, including polyborosilane, polyborosiloxane, polyborosilazane, and their derivatives are often used as the precursors for fabricating borosilicon ceramics [63-65]. Compared to the traditional organosilicon polymers, the addition of metal elements (such as zirconium, iron, etc.) on the backbone or side chain of preceramic polymers can fabricate cermet [66-70].

To date, many studies have demonstrated the development on the simple, cheaper methods to

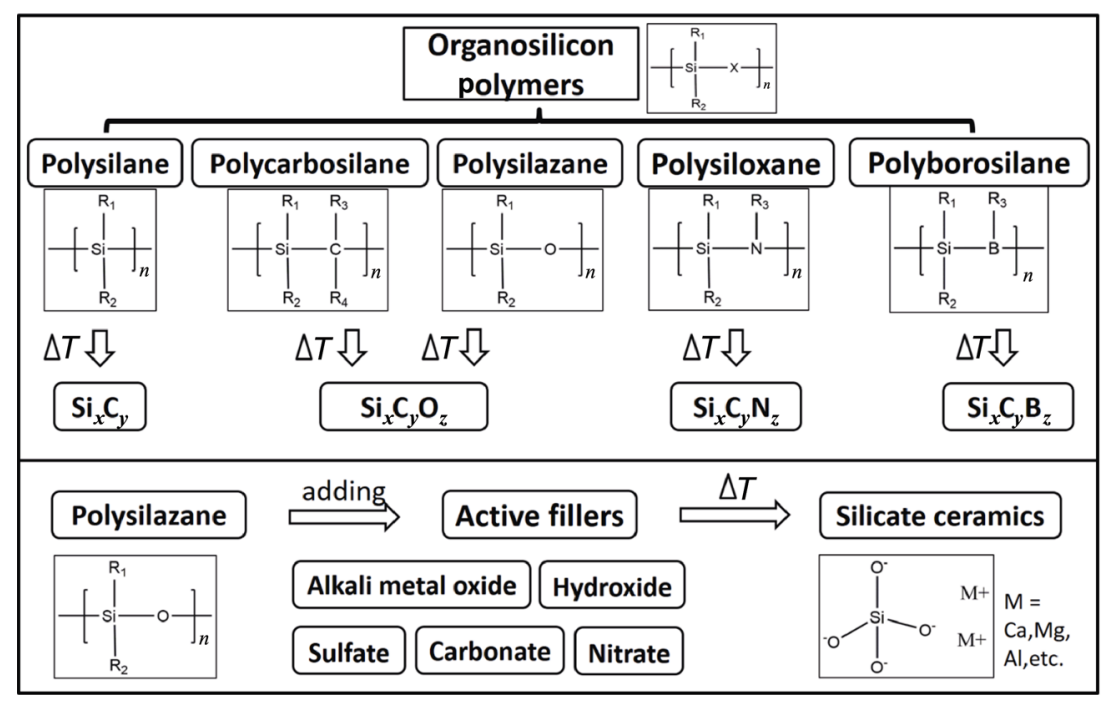

Fig. 1 Schematic illustration of silicon-based ceramics derived from the common organosilicon polymers. 
synthesize the functionalized organosilicon polymers with high ceramic yield, as well as the relationships between the structure and properties of the final polymer-derived ceramics. However, the properties of final polymer-derived ceramics are either greatly determined by subsequent processes including the shaping, cross-linking, and sintering.

\section{Processing of organosilicon polymers}

After synthesis of organosilicon polymers, shaping, cross-linking, pyrolysis, and ceramization are subsequent processes to fabricate silicon-based ceramics (Fig. 2). As known, it is not easy for silicon-based ceramics to directly shape into a specific model due to the poor rheology properties of raw powders. Generally, the shaping of ceramics is always assisted by adding a certain amount of polymer binders, which are dissolved in an organic or aqueous solution, and will be burned out during sintering. Moreover, the fabrication process of ceramics is complicated, including the preparation of ceramic powders, shaping assisted by binders, and sintering for densification. As silicon-based preceramic sources, organosilicon polymers are able to shape directly without the preparation of ceramic powders, and a variety of methods can be applied for the shaping of organosilicon polymers, such as injection molding, blow molding, extrusion molding, coating, electrospinning, $3 \mathrm{D}$ printing, etc.

However, the cross-linking of organosilicon polymers is very important for the fabrication of silicon-based ceramics. The cross-linking of organosilicon polymers is usually triggered by radiation or catalysts at low temperature (ca. $200-500{ }^{\circ} \mathrm{C}$ ), which can not only improve the degrees of polymerization, but also control the weight loss of the precursors during the pyrolysis. Higher cross-linked precursors usually possess a higher ceramic yield. Moreover, the process of cross-linking is a key factor to keep the shapes during the pyrolysis and ceramization [71]. It should be mentioned that the cross-linking might not be necessary when a large amount of fillers are mixed with organosilicon polymers, because the fillers can support the matrix to maintain its shape.

In general, the sintering process including heating rate, reaction atmosphere, reaction temperature, and holding time, would determine the phase composition and microstructure of the final ceramics. The sintering process of the organosilicon polymers involves the pyrolysis and a polymer-to-ceramic transformation from preceramic precursors into amorphous or crystalline ceramics. Different silicon-based ceramics can be fabricated and the compositions can be adjusted by choosing the organosilicon polymers. However, the silicon-based ceramics derived from organosilicon polymers often suffer from the cracks, forming pores, and large shrinkage. Previous studies demonstrated that it is possible to fabricate relatively dense and crack-free ceramics by adding fillers into preceramic polymers [72]. Interestingly, the addition of active fillers, which could react with precursors or reaction atmosphere, has been a new and efficient strategy to fabricate silicate ceramics $[73,74]$. Therefore, varieties of silicon-based ceramics are possible to be fabricated from organosilicon polymers.

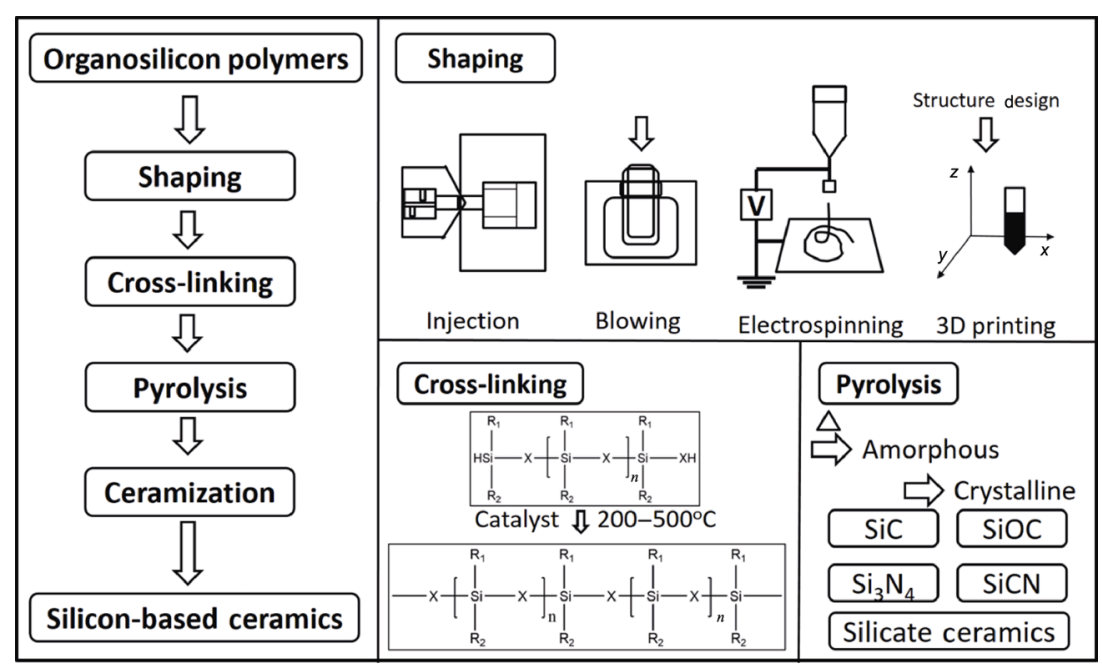

Fig. 2 Processes from organosilicon polymers to silicon-based ceramics. 


\section{3D printed organosilicon polymer-derived silicon-based ceramics}

3D printing is a good choice to fabricate special structured materials due to the precise design and control for the architecture and structure by computer aided design (CAD) and computer aided manufacturing (CAM) [75-82], which has been utilized in fabricating polymer-derived ceramics in recent years due to its ability to control the architecture or porous structure precisely. According to the different shaping principles, 3D printing technique can be divided into six modes, which include modeling (FDM), stereolithography (SLA), selective laser sintering (SLS), powder-based printing (PB), inkjet printing (IP), and direct ink writing (DIW). Among them, SLA, PB, and DIW have been successfully utilized for the fabrication of polymer-derived ceramics, including $\mathrm{SiC}, \mathrm{SiOC}$, and silicate bioceramics. The organosilicon polymer-derived silicon-based ceramics shaped by $3 \mathrm{D}$ printing technique are summarized in Table 2.

For example, Eckel et al. [5] fabricated $\mathrm{SiOC}$ ceramics with some complex structures by stereolithography 3D printing of organosilicon polymers (Fig. 3). The starting organosilicon polymer, mercaptopropyl-methylsiloxane, was mixed with vinylmethoxysi-loxane and UV free-radical photo initiator. After 3D printing under UV laser radiation, the complex structures such as corks crew, microlattices, and honeycomb were formed (Figs. 3(e)-3(h)). Finally, SiOC ceramics with complex structures were obtained after the pyrolysis of the green structures at $1000{ }^{\circ} \mathrm{C}$ in argon. Importantly, the
SiOC ceramics with a honeycomb structure showed a higher compressive failure strength of $163 \mathrm{MPa}$ and the high temperature stability at $1300{ }^{\circ} \mathrm{C}$. Li et al. [83] fabricated $\mathrm{SiBCN}$ ceramics with complex shapes from organosilicon polymers by using digital light processing 3D printing. The solution for 3D printing was prepared by blending polyborosilazane with photosensitive acrylate monomers. $405 \mathrm{~nm}$ light was used for shaping, and the green structures were sintered over $1200{ }^{\circ} \mathrm{C}$ to obtain SiBCN ceramics. Similarly, Zanchetta et al. [84], Fu et al. [85], and de Hazan et al. [86] also fabricated SiOC ceramics with complex structures by stereolithography $3 \mathrm{D}$ printing. The fabrication processes involve the preparation of a light-sensitive organosilicon polymer solution, 3D printing assisted under light exposure and sintering to ceramics. For stereolithography 3D printing, organosilicon polymers decide the final ceramics' component and the photosensitive agents decide the shaping accuracy.

Zocca et al. [87] fabricated a Kagome structure for polymethylsilsesquioxanes by $3 \mathrm{D}$ powder-based printing, and the $\mathrm{SiOC}$ ceramics kept the original porous structure after the process of ceramization over $1000{ }^{\circ} \mathrm{C}$. The organosilicon polymer solution was dried, ball milled, and sieved. Subsequently, the treated powders were printed by using isopropanol as the printing liquid by a layer-by-layer deposition, and then the green scaffolds with complex structure were sintered for SiOC ceramics. Chen et al. [88] fabricated SiC ceramics by direct ink writing. A printable paste was prepared by dissolving polycarbosilane into N-hexane solution. Then, the solutions were filled in a syringe and passed as a filament

Table 2 A summary of the organosilicon polymer-derived silicon-based ceramics fabricated with 3D printing technique

\begin{tabular}{|c|c|c|c|c|}
\hline $3 \mathrm{D}$ printing type & Organosilicon polymer (fillers) & Derived silicon-based ceramics & Structure & Reference \\
\hline Stereolithography & Polysiloxane & $\mathrm{SiOC}$ & Corks crew, micro-lattices, and honeycomb & [5] \\
\hline Stereolithography & Polyborosilazane & $\mathrm{SiBCN}$ & $\begin{array}{l}\text { Hollow porous spheres, honeycomb, } \\
\text { and porous scaffolds }\end{array}$ & [83] \\
\hline Stereolithography & Polysiloxane & $\mathrm{SiOC}$ & Micro-pore scaffolds & {$[84,85]$} \\
\hline Stereolithography & Polycarbosilane & $\mathrm{SiC}, \mathrm{SiOC}$ & Gear, dodecahedron, tower, etc. & [86] \\
\hline Powder-based printing & Polysiloxane & $\mathrm{SiOC}$ & Kagome structure & [87] \\
\hline Powder-based printing & Polysiloxane (bioactive glass) & $\mathrm{CaSiO}_{3} /$ bioactive glass & Macro-pore scaffolds & [94] \\
\hline Direct ink writing & Polycarbosilane & $\mathrm{SiC}$ & Macro-pore scaffolds & [88] \\
\hline Direct ink writing & Polysiloxane (graphene oxide) & SiOC/graphene oxide & Macro-pore scaffolds & [89] \\
\hline Direct ink writing & Polysiloxane $\left(\mathrm{CaCO}_{3}\right)$ & $\mathrm{CaSiO}_{3}$ & Macro-pore scaffolds & [73] \\
\hline Direct ink writing & Polysiloxane $\left(\mathrm{CaCO}_{3}, \mathrm{ZnO}\right)$ & $\mathrm{Ca}_{2} \mathrm{ZnSi}_{2} \mathrm{O}_{7}$ & Macro-pore scaffolds & {$[90,91]$} \\
\hline Direct ink writing & Polysiloxane $\left(\mathrm{CaCO}_{3}, \mathrm{Mg}(\mathrm{OH})_{2}\right)$ & $\mathrm{CaSiO}_{3} / \mathrm{CaMgSi}_{2} \mathrm{O}_{6}$ & Macro-pore scaffolds & [93] \\
\hline Direct ink writing & Polysiloxane $\left(\mathrm{CaCO}_{3}\right)$ & $\beta-\mathrm{Ca}_{2} \mathrm{SiO}_{4}$ & Macro-pore scaffolds & [183] \\
\hline
\end{tabular}


(a)

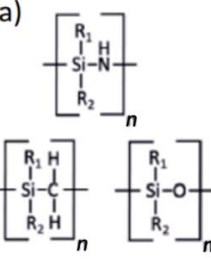

UV curable monomers \& UV photo initiator

(e)

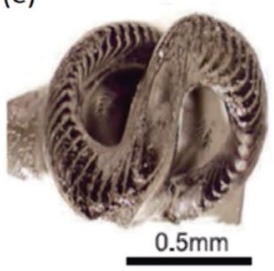

(b)

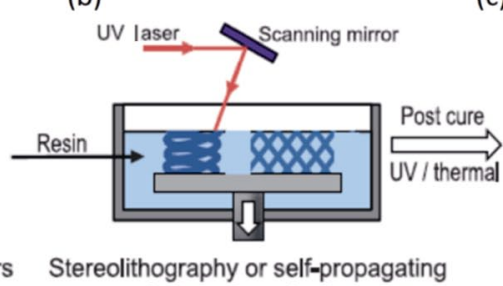
photo-polymerization

(f)

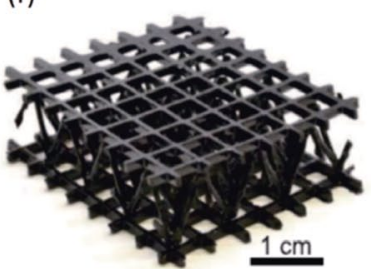

(c)

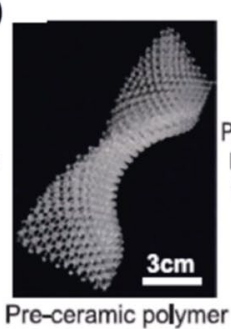

(g)

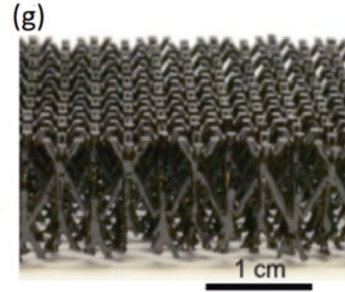

(d)

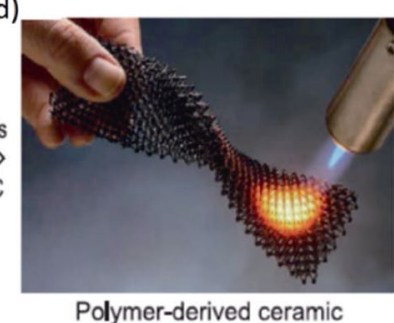

(h)

Fig. 3 Schematic illustration of 3D printing of polymer-derived ceramics. (a) UV-curable organosilicon monomers are mixed with photo initiator. (b) The resin is exposed with UV light in a SLA 3D printer or through a patterned mask. (c) A preceramic polymer part is obtained. (d) Pyrolysis converts the polymer into a ceramic. Examples: (e) SLA 3D printed corks crew. (f, g) SPPW formed microlattices. (h) Honeycomb. Reproduced with permission from Ref. [5], (C) American Association for the Advancement of Science 2016.
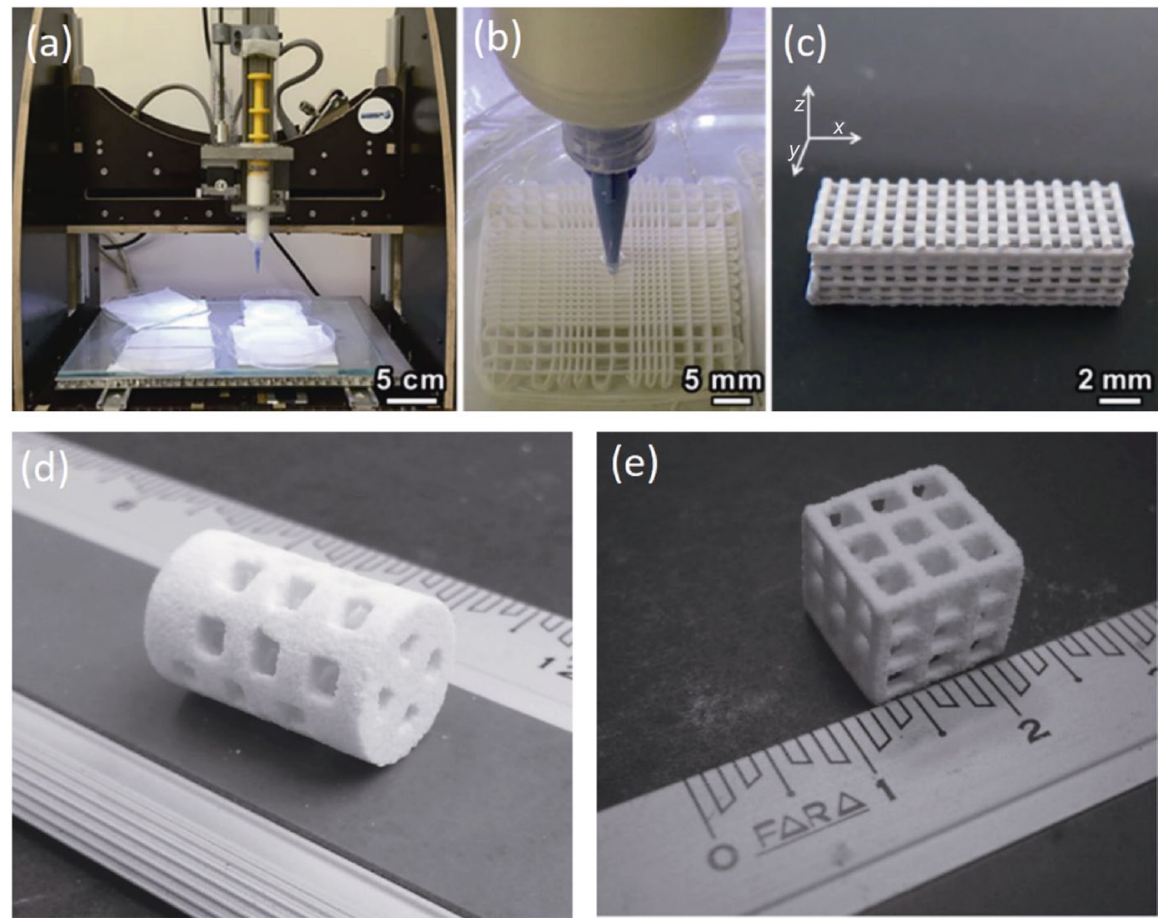

Fig. 4 (a) 3D printer equipped with syringe for silicone-based ink. (b) Detail of the printing process carried out in oil bath. (c) Overview of a 3D-printed scaffold with orientation of the axes. Reproduced with permission from Ref. [93], (C) Elsevier Ltd. 2017. (d, e) Images of 3D powder printed scaffolds. Reproduced with permission from Ref. [94], (C) IOP Publishing Ltd. 2015.

through the nozzle to deposit a designed marco-porous structure $(100-400 \mu \mathrm{m})$. Finally, black $\mathrm{SiC}$ with complex structures was obtained after cross-linking $\left(200{ }^{\circ} \mathrm{C}\right)$ and pyrolysis at $1400{ }^{\circ} \mathrm{C}$. Pierin et al. [89] successfully fabricated micro-sized SiOC ceramics by direct ink writing of organosilicon polymers. Polymethylsilses- quioxane was dissolved into isopropyl alcohol for 3D printing and the rheological property was adjusted by adding different content of cross-linked silicone resin solid particles. After cross-linking and pyrolysis at $1000{ }^{\circ} \mathrm{C}$ in argon, the final SiOC ceramics maintained the porous structure and had the compressive strength 
of $2.5 \pm 0.97 \mathrm{MPa}$. Interestingly, the printed scaffolds showed a better retention of the structure upon heating and reduced shrinkage with less cracks by adding a little amount of graphene oxide (GO) flakes.

The fabrication of organosilicon polymer-derived silicate ceramics by $3 \mathrm{D}$ printing is similar to the processes of fabricating $\mathrm{SiC}, \mathrm{SiOC}$, etc. The only difference is that raw material for silicate ceramic contains active fillers. Direct ink writing was first employed to shape organosilicon polymers with fillers to obtain silicate ceramics by Bernardo et al. [73]. A printable paste was prepared by mixing $\mathrm{CaCO}_{3}$ fillers into polysiloxane solution for $3 \mathrm{D}$ printing, and the final silicate ceramics were obtained after a sintering process. In Zocca et al.'s [90] and Elsayed et al.'s [91] works, porous hardystonite $\left(\mathrm{Ca}_{2} \mathrm{ZnSi}_{2} \mathrm{O}_{7}\right)$ bioceramic scaffolds were fabricated by direct ink writing. Polysiloxane with little fumed silica was dissolved into isopropanol, and then mixed with $\mathrm{ZnO}$ and $\mathrm{CaCO}_{3}$ powders to prepare printable ink. The final hardystonite scaffolds possessed large porosity $(>76 \%$ ) with a compressive strength of ca. 2.5 MPa. Moreover, Fiocco et al. [92] fabricated $\mathrm{CaCO}_{3} / \mathrm{SiO}_{2}$ composite scaffolds by direct ink writing. A paste composed of polysiloxane and $\mathrm{CaCO}_{3}$ was prepared, following cross-linking at $350{ }^{\circ} \mathrm{C}$ and sintering at $600{ }^{\circ} \mathrm{C}$. The fabricated $\mathrm{CaCO}_{3} / \mathrm{SiO}_{2}$ scaffolds had open porosity $(56 \%-64 \%)$ and compressive strength of 2.9-5.5 MPa. Elsayed et al. [93] reported the wollastonite/diopside composite scaffolds by direct ink writing. The obtained scaffolds possessed regular geometries, a high compressive strength (3.9-4.9 MPa), and a large amount of porosity $(68 \%-76 \%)$. On the other hand, powder-based 3D printing was successfully used to fabricate wollastonite/bioactive glass scaffolds by Zocca et al. [94]. Polysiloxane, calcium carbonate, and AP40 bioactive glass powders were used as deposit layers with a thickness of $150 \mu \mathrm{m}$, and a mixture of 1-hexanol and hexylacetate was used as a printing liquid. Porous wollastonite/bioactive glass scaffolds with a porosity of $80 \%$ and a biaxial flexural strength of ca. $6 \mathrm{MPa}$ were fabricated after pyrolysis at $900{ }^{\circ} \mathrm{C}$ (Fig. 4).

Due to the perfect shaping ability of organosilicon polymers, 3D printing technique provides a great choice for fabricating silicon-based ceramics with complex structure or porosity. Therefore, 3D printing technique combines with organosilicon polymer-derived strategy would be great potential for the fabrication of silicon-based ceramics in practical application.

\section{Silicon-based ceramics derived from organosilicon polymers}

Silicon as a common rich element in the earth's crust is widely used for synthesizing polymers and inorganic non-metallic materials. Silicon-based ceramics can be classified into non-oxide silicon-based ceramics and silicate ceramics. Non-oxide silicon-based ceramics can be further divided into binary, ternary, and multivariate systems according to their components. However, the compositions of all silicon-based ceramics derived from organosilicon polymers are complicated; for instance, the residual carbon in $\mathrm{Si} / \mathrm{N}$ ceramics derived from polysilazane will be detected inevitably. Therefore, the following binary or ternary system silicon-based ceramics only consider the main elements in the ceramics. In biomedical applications, non-oxide silicon-based ceramics are less popular than silicate ceramics. However, with the development of polymer-derived strategy, organosilicon polymer-derived non-oxide silicon-based ceramics are seeming to be useful. On the other hand, there have been many studies on organosilicon polymer-derived silicate ceramics for biomedical applications. The structure and porosity are two important factors for bioceramics, and the organosilicon polymer-derived strategy facilitates the shaping process. Furthermore, the components of organosilicon polymer-derived ceramics could be well controlled and the silicon component is important for biomedical applications.

\section{1 Binary silicon-based ceramics}

$\mathrm{SiC}$ and $\mathrm{Si}_{3} \mathrm{~N}_{4}$ are two most common binary silicon-based ceramics, which are derived from polycarbosilane and carbon-free polysilazane. Compared to the commercial methods to fabricate binary silicon-based ceramics such as solid state, solid-gas reaction, organosilicon polymer-derived ceramics method facilitates the shaping process and greatly decreases the reaction energy consumption. Importantly, organosilicon polymer-derived $\mathrm{SiC}$ and $\mathrm{Si}_{3} \mathrm{~N}_{4}$ ceramics show remarkable properties such as mechanical strength, chemical stability, etc.

Polycarbosilanes, which can be directly converted to $\mathrm{SiC}$ after the pyrolysis, have been widely used for fabricating $\mathrm{SiC}$ powders, foams, fibers, monoliths, coating, and composites [37,95-98]. For example, Wang et al. [37] prepared carbon-rich $\mathrm{SiC}$ powders via the pyrolysis of polycarbosilanes (Fig. 5). The polycarbosilanes were 

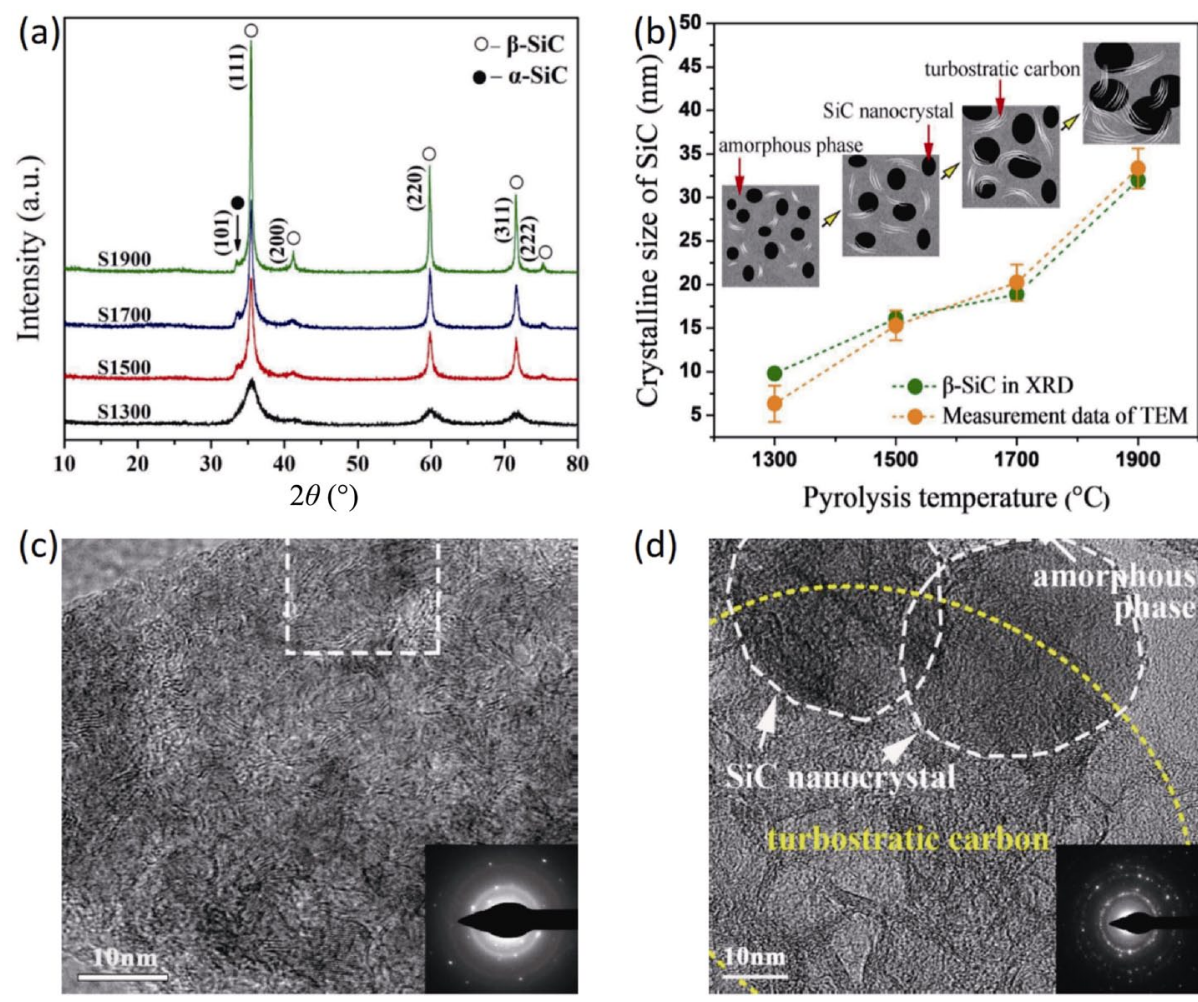

(d)

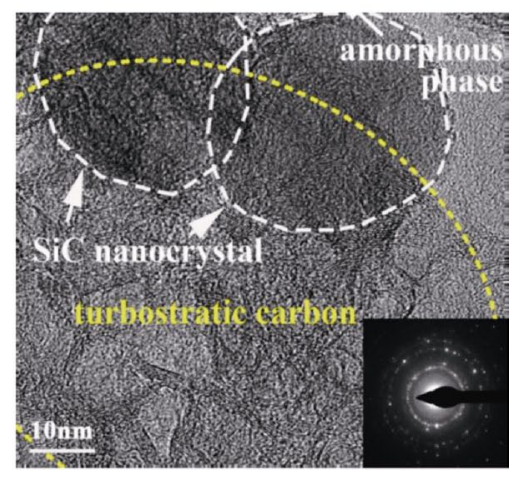

Fig. 5 (a) XRD patterns of the polycarbosilane-derived $\mathrm{SiC}$ ceramics pyrolyzed at 1300,1500, 1700, and $1900{ }^{\circ} \mathrm{C}$. (b) The sizes of $\mathrm{SiC}$ nanocrystals pyrolyzed at different temperatures and schematic illustration of microstructural evolution of the polycarbosilanes-derived SiC ceramics. HRTEM images of the polycarbosilanes-derived SiC ceramics pyrolyzed at (c) $1300{ }^{\circ} \mathrm{C}$ and (d) $1900{ }^{\circ} \mathrm{C}$ for characterizing the microstructure of the SiC nanocrystals and carbon phase in ceramics. Reproduced with permission from Ref. [37], C) Elsevier Ltd and Techna Group S.r.1. 2017.

cross-linked, followed by the pyrolysis process at a temperature up to $1900{ }^{\circ} \mathrm{C}$. With the increase of pyrolysis temperature, crystallization degree increased and these diffraction peaks of $\beta$-SiC became narrower in width and stronger in intensity, as well as the size of $\mathrm{SiC}$ crystals increased and the $\mathrm{SiC}$ crystal became turbostratic from amorphous. Mishra et al. [95] fabricated $\mathrm{SiC}$ foams with a controlled porosity. In their study, polycarbosilanes were synthesized via the thermal backbone rearrangement of polydimethylsilane (PDMS) granules, and then they were modified with epoxy by dissolved in epoxytetrahydrofuran solution. $\mathrm{SiC}$ foams were derived from the pyrolysis of polycarbosilanes at $1000{ }^{\circ} \mathrm{C}$ and ceramization over $1200{ }^{\circ} \mathrm{C}$ in a vacuum furnace. With increasing the content of epoxy, the porosity increased and the density decreased. At the same time, the compressive strength increased with the ceramization temperature.

Eick and Youngblood [99] fabricated $\mathrm{SiC}$ nanofibers by the electrospinning of the mixture of polysilanes and polystryrene, followed by a pyrolysis process. A polysilane solution was prepared for electrospinning, and then was exposed to UV radiation for cross-linking. After a pyrolysis at $1200{ }^{\circ} \mathrm{C}$, the core-shell structured $\mathrm{SiC} / \mathrm{SiO}_{2}$ nanofibers with an average diameter of $50 \mathrm{~nm}$ were obtained. Continuous $\mathrm{SiC}$ fibers with different thickness of carbon layer were directly prepared by changing the pyrolysis models for organosilicon polymers $[100,101]$. Actually, the development of polymer-derived $\mathrm{SiC}$ fibers has been summarized by Flores et al. [102] and Bunsell and Piant [103]. The first generation preceramic polymer-derived $\mathrm{SiC}$ fibers possessed high tensile strength but low modulus and thermal stability. The second generation $\mathrm{SiC}$ fibers are fabricated by decreasing the oxygen content, and they had better high-temperature and creep properties. The third generation $\mathrm{SiC}$ fibers with near stoichiometric ratio have optimal tensile strength, modulus, and thermal stability, which have been commercialized for practical applications.

SiC-based composites have been applied worldwide due to high temperature strength, low density, and good thermal stability [104-106]. To date, varieties of studies demonstrated the fabrication of SiC-based composites using polycarbosilanes. For example, Ma et al. [96] 
investigated the effects of high-temperature annealing on the microstructures and mechanical properties of the carbon fiber reinforced $\mathrm{SiC}\left(\mathrm{C}_{\mathrm{f}} / \mathrm{SiC}\right)$ composites derived from organosilicon polymers. The flexural strength of the composites gradually decreased with the increase of annealing temperature $\left(1600-1800{ }^{\circ} \mathrm{C}\right)$ and annealing time. Mu et al. [104] and Liu and Tian [107] fabricated $\mathrm{SiC}$ reinforced $\mathrm{SiC}$ matrix $\left(\mathrm{SiC}_{\mathrm{f}} / \mathrm{SiC}\right)$ with $\mathrm{BN}$ interphase from polycarbosilanes and different boron, nitrogen sources, and the mechanical strength of the composites was enhanced by introducing $\mathrm{BN}$ interphase significantly. In addition, many other SiC-based composites derived from organosilicon polymers have been fabricated, such as $\mathrm{ZrC} / \mathrm{SiC}, \mathrm{Al}_{2} \mathrm{O}_{3} / \mathrm{SiC}$, $\mathrm{SiAlON} / \mathrm{SiC}$, carbon nanotube/ $\mathrm{SiC}$, etc. [108-113].

$\mathrm{SiC}$ ceramics show high mechanical strength, high thermal shock resistance, low thermal expansion coefficient, good chemical stability at high temperature, and semi-conducting, which is recognized as a promising material for semiconductor and applied in extreme environments [37,95,114]. In biomedical applications, $\mathrm{SiC}$ has been proposed as a candidate for bone implants or coating due to the high mechanical strength and ability for loading and releasing antibiotics [115-118]. Díaz-Rodríguez et al. [115] found that biomorphic SiC was a promising loaded system and able to control the release of vascular endothelial growth factor (VEGF), leading to the proliferation of human umbilical vein endothelial cells (HUVECs) and new bone blood vessel formation. Gryshkov et al. [116] proved that porous $\mathrm{SiC}$ was cytocompatible, and its re-cultivation efficiency as well as metabolic activity were improved after coated with hydroxyapatite (HA) and $\mathrm{HA} /$ zirconia $\left(\mathrm{HA} / \mathrm{ZrO}_{2}\right)$, which showed great potential in porous carrier materials for bone implants.

$\mathrm{Si}_{3} \mathrm{~N}_{4}$ is another representative for binary silicon-based ceramics, which is famous for its excellent mechanical properties, low coefficient of thermal expansion, and good resistance to thermal shock $[119,120]$. Branched $\alpha-\mathrm{Si}_{3} \mathrm{~N}_{4}$ ceramics have been successfully fabricated using polysilazanes by Fu et al. [121-123]. Polysilazene was solidified by thermal cross-linking, following a heating treatment at $1250{ }^{\circ} \mathrm{C}$ in a $\mathrm{N}_{2}$ atmosphere. The growth of branched $\mathrm{Si}_{3} \mathrm{~N}_{4}$ ceramics was attributed to a vapor-liquid-solid mechanism [122]. Jiang et al. [124,125] fabricated quartz fiber reinforced nitride composites $\left(\mathrm{Si}_{3} \mathrm{~N}_{4}-\mathrm{BN}\right)$ by polyborosilazane pyrolysis. The results showed that the composite processes a high flexural strength (101.8 MPa) and a good thermal-physical performance. However, there are few works on organosilicon polymer-derived $\mathrm{Si}_{3} \mathrm{~N}_{4}$ ceramics due to the existence of carbon in most polysiloxanes, which results in the formation of $\mathrm{SiCN}$ ceramics instead.

Similar to $\mathrm{SiC}, \mathrm{Si}_{3} \mathrm{~N}_{4}$ ceramics show potentials in biomedical applications. Das et al. [126], Bodišová et al. [127], and Cappi et al. [129] proved that $\mathrm{Si}_{3} \mathrm{~N}_{4}$ was non-cytotoxic evaluated by human osteoblast-like cells (MG63) and human fibroblast cells, which shows great potential for biomedical applications. Pezzotti et al. [128] found that $\mathrm{Si}_{3} \mathrm{~N}_{4}$ possessed an inherently anti-infective surface chemistry, against bacterial loading. The $\mathrm{Si}-\mathrm{N}$ covalent bond led the formation of silanol and ammonia. Oxidation of ammonia into hydroxylamine and highly volatile species such as nitric oxide and peroxynitrite could damage bacterial DNA and membrane components, and then altered protein structures.

Polymer-derived binary silicon-based ceramics including $\mathrm{SiC}$ and $\mathrm{Si}_{3} \mathrm{~N}_{4}$ have aroused great attention due to their excellent mechanical property, thermal stability, etc. Many studies have emphasized on how to fabricate different $\mathrm{SiC}$ and $\mathrm{Si}_{3} \mathrm{~N}_{4}$ architectures or their composites to fulfill various applications. In biomedical applications, organosilicon polymer-derived $\mathrm{SiC}$ and $\mathrm{Si}_{3} \mathrm{~N}_{4}$ have shown great promising in bone regeneration and antibacterial materials.

\section{2 Ternary silicon-based ceramics}

Polysiloxane, polysiloxane, and polycarbosilane are most commonly used to fabricate ternary silicon-based ceramics such as silicon oxycarbide (SiOC) and silicon carbonitride ( $\mathrm{SiCN})$. By processing different organosilicon polymers, the composition of ternary silicon-based ceramics can be adjusted within a certain range. Moreover, the properties of $\mathrm{SiOC}$ and $\mathrm{SiCN}$ can also be controlled by different processing treatments.

Silicon carbide oxide ( $\mathrm{SiOC}$ ), especially with porous structures has gained much attention due to its excellent oxidation resistance, high temperature stability, and thermal-mechanical durability, and has been used as catalyst supports, battery anodes, insulation materials, and gas sensors [89,130-132]. Importantly, polymerderived SiOC has also been studied for biomedical applications. To date, the fabrication of porous SiOC derived from organosilicon polymers is a popular strategy, and porous structure of $\mathrm{SiOC}$ can be created by $3 \mathrm{D}$ printing, direct foaming, sacrificial templates, freezing casting, etc. 
Organosilicon polymers are capable of direct foaming due to its controllable rheological properties and the ability to form pores during their shrinkage when pyrolysis. Idesaki and Colombo [4] and Vakifahmetoglu and Colombo [133] fabricated SiOC foams by direct foaming technique, and the pore parameters could be controlled by turning the composition of starting materials and the process of heat treatments. For example, gradient-hierarchic-aligned porous $\mathrm{SiOC}$ ceramics were fabricated by adding different amounts of polydimethylsiloxane in the mixed starting solution, and the open porosity and average pore diameter could be controlled at $69.9 \%-83.4 \%$ and $0.59-1.25 \mathrm{~mm}$, respectively [134]. Except that, polyurethane (PU) and polymethyl methacrylate (PMMA) are two most common sacrificial templates and have been applied to fabricate polymer-derived porous SiOC ceramics [135-138]. Colombo et al. [136-138] fabricated macro (100-600 $\mu \mathrm{m}$ ) and micro (ca. $8 \mu \mathrm{m}$ ) cellu br SiOC fo ams by introducing PU and polymethyl methacrylate (PMMA) microbeads as sacrificial templates into polysiloxane, and a controllable bulk density $\left(0.25-0.85 \mathrm{~g} / \mathrm{cm}^{3}\right)$ and compressive strength (ca. 2-18 MPa) could be achieved. To fabricate highly ordered mesoporous SiOC monoliths, mesoporous carbon $\mathrm{CMK}-3$ as a direct template was proposed to fill into liquid polysiloxane [139]. Mesoporous silica SBA-15 derived mesoporous carbon CMK-3 template was nanocasted, followed by cross-linking and pyrolysis in argon. The carbon templates were removed at $1000{ }^{\circ} \mathrm{C}$, and the $\mathrm{SiOC}$ exhibited crack-free, ordered two-dimensional hexagonal P6mm symmetry, and high specific surface area $\left(602-616 \mathrm{~m}^{2} / \mathrm{g}\right)$. Except for PU and mesoporous carbon, other sacrificial templates including wood biomass, rice bran, polystyrene sphere, and layered double hydroxide template have also been reported [140-144]. Freezing casting method is another choice to fabricate porous SiOC ceramics by using organosilicon polymers. Naviroj et al. [145] proposed a solution freezing casting method to fabricate organosilicon polymer-derived porous SiOC ceramics. The polysiloxane solution was partially cross-linked. Porous SiOC structure could be achieved after freezing casting and pyrolysis. Soltani et al. [146] also developed a freezing casting route towards macroporous $\mathrm{SiOC} / \mathrm{SiO}_{2}$ composites. It demonstrated that the pre-crosslinking of the starting organosilicon polymer reduced the shrinkage, but resulted in the decreased mechanical strength of the composites due to the inhomogeneous cell walls.
Since organosilicon polymer-derived ceramics is a good strategy for fabricating porous SiOC ceramics and porous structure has been widely utilized in biomedical materials, this strategy has broadened the use of SiOC in biomedical applications. Zhuo et al. [147] reported that the organosilicon polymer-derived SiOC could activate coagulation of whole human blood plasma, and this property was related with the surface stoichiometry of oxygen and carbon because it decided the water wettability of SiOC. The stoichiometry of oxygen and carbon can be easily adjusted by different raw organosilicon polymers or chemical post-treatments, leading to a promising use for $\mathrm{SiOC}$ in blood-contact applications. Grossenbacher et al. [148] demonstrated that the polymer-derived ceramics were stable and low toxicity, and their electrical conductivity could be adjusted by carbon doping, which could be used in implantable electrode applications such as pacemakers. Tamayo et al. [149-151] fabricated mesoporous SiOC for controlled drug delivery. A mixture of organosilicon sol was prepared and aged to form gel by the addition of $\mathrm{NH}_{4} \mathrm{OH}$ solution, which transferred into SiOC after pyrolysis at $1100{ }^{\circ} \mathrm{C}$. The $\mathrm{SiOC}$ presented bimodal porous structure with pores of 6 and $100 \mathrm{~nm}$ size, resulted to a faster drug penetration than mesoporous active carbon. Vakifahmetoglu et al. [152] fabricated hierarchically SiOC with micro- and meso-pores by organosilicon polymer-derived strategy as a multi drug release system (Fig. 6). A mixed organosilicon polymer solution was stirred homogeneously firstly, and hierarchically porous SiOC with $774 \mathrm{~m}^{2} / \mathrm{g}$ specific surface was obtained after pyrolysis at $1300{ }^{\circ} \mathrm{C}$ and etching by hydrofluoric acid (HF). The obtained SiOC showed a better capacity for delivery of two different sized drugs (bovine serum albumin (BSA) and vancomycin), and the anti-bacterial activity of the hierarchically porous SiOC was stronger than MCM-41 mesoporous silica tested by the time-kill evaluation.

Silicon carbonitride $(\mathrm{SiCN})$ derived from polysilazane possesses the outstanding properties including thermal stability, high mechanical strength, and excellent fracture toughness, which shows great potential for high temperature and structure applications [153,154]. In general, amorphous $\mathrm{SiCN}$ ceramics can be obtained at $1000{ }^{\circ} \mathrm{C}$, which are transferred into $\mathrm{SiC}$ and $\mathrm{Si}_{3} \mathrm{~N}_{4}$ phases with free carbon at a higher temperature, and then $\beta$-SiC could be formed from the reaction between $\mathrm{Si}_{3} \mathrm{~N}_{4}$ and free carbon over $1800{ }^{\circ} \mathrm{C}$ [73,147-150].

Iwamoto et al. [155] demonstrated the crystallization 

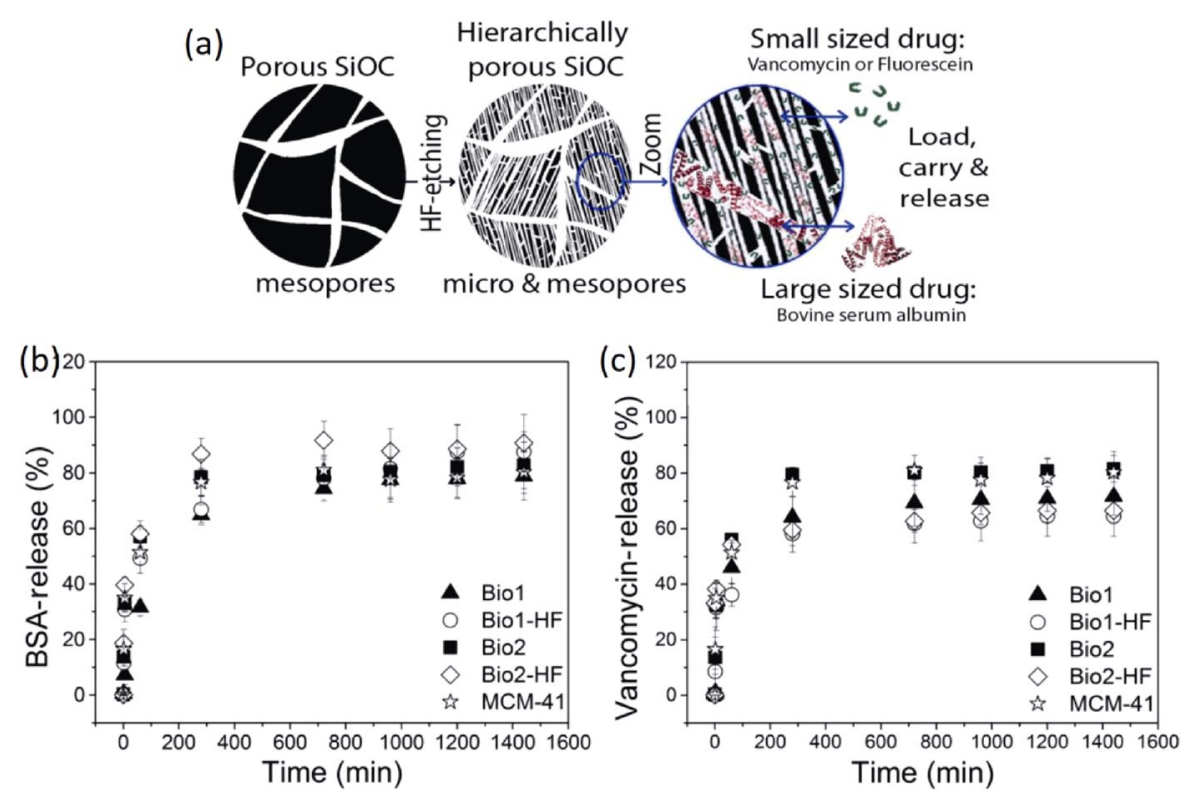

Fig. 6 (a) Scheme illustration of the microstructure of the hierarchically porous SiOC and its drug delivery system. Release curve of (b) BSA and (c) vancomycin loaded SiOC in PBS buffer. Reproduced with permission from Ref. [152], C Elsevier Ltd. 2017.

behavior of the polymer-derived $\mathrm{SiCN}$ ceramics. SiCN ceramics with a controllable atomic ratio of $\mathrm{C} / \mathrm{Si}$ could be fabricated by changing the proportion of polycarbosilane and polysilazane, and the $\mathrm{Si}_{3} \mathrm{~N}_{4}$ crystallization temperature of $\mathrm{SiCN}$ increased with the increase of $\mathrm{C} / \mathrm{Si}$ ratio. The crystallization behavior of the organosilicon polymer-derived amorphous $\mathrm{SiCN}$ was governed by chemical composition, molecular structure, and chemical homogeneity. The existence of nitrogen retarded the crystallization of $\mathrm{SiC}$ owing to the high nitrogen content in the organosilicon polymers leading to the formation of $\mathrm{SiN}_{4}$. Furthermore, Mera et al. [58] successfully controlled the atomic ratio of $\mathrm{C} / \mathrm{Si}$ by introducing phenyl into polysilylcarbodiimides. Also, different substituents attached to the backbone of organosilicon polymers could induce different thermal behaviors of the SiCN ceramics. With a higher amount of carbon, an enhanced thermal stability of $\mathrm{SiCN}$ was achieved due to the protection of the amorphous silicon nitride by graphene layer derived from carbon in the organosilicon polymers.

Nangrejo et al. [156] fabricated $\mathrm{SiC} / \mathrm{Si}_{3} \mathrm{~N}_{4}$ foams by immersing a polyurethane foam into a polysilane solution mixed with different proportion of $\mathrm{Si}_{3} \mathrm{~N}_{4}$ powders. The polysilanes were used as $\mathrm{SiC}$ precursors, while $\mathrm{Si}_{3} \mathrm{~N}_{4}$ powders acted as inert fillers to obtain $\mathrm{SiC} / \mathrm{Si}_{3} \mathrm{~N}_{4}$ composite, which showed well-defined open-cell structures with macro struts. Similarly, Degenhardt et al. [154] reported a method to fabricate porous $\mathrm{SiCN}$ ceramics by using polycarbosilazane as precursors and $\mathrm{Si}_{3} \mathrm{~N}_{4}$ powders as inert fillers. After pyrolysis at $1000{ }^{\circ} \mathrm{C}$, $\mathrm{SiCN}$ partially filled the interstices between the inert $\mathrm{Si}_{3} \mathrm{~N}_{4}$, and thus porous $\mathrm{SiCN} / \mathrm{Si}_{3} \mathrm{~N}_{4}$ ceramics with about $34 \%$ porosity were obtained. However, subsequent gas pressure sintering led to the formation of $\mathrm{SiC}$ and $\mathrm{Si}_{3} \mathrm{~N}_{4}$ from $\mathrm{SiCN}$. On the other hand, the SiCN-based composites can also be derived from organosilicon polymers. For example, Graczyk-Zajaca et al. [157] developed $\mathrm{SiCN} /$ graphite composite derived from polysilazanes as a negative electrode in lithium-ion batteries. A commercial preceramic polysilazane and graphite with a 1:1 weight ratio was used to fabricate $\mathrm{SiCN} /$ graphite composite after a pyrolysis at 950,1100 , or $1300{ }^{\circ} \mathrm{C}$. Reinold et al. [158] reported the carbon-rich $\mathrm{SiCN}$ ceramics derived from branched polysilazane and polysilylcarbodiimide for anode material in lithium-ion batteries.

To our best knowledge, there are also some studies on multivariate silicon-based ceramics. In general, multivariate silicon-based ceramics can be fabricated via two methods. For example, quaternary ceramics such as SiCBN can be derived directly from boron-containing organosilicon polymers $[63,64,159]$, of which the fabrication processes are similar to those of binary and ternary polymer-derived ceramics. Except for the direct pyrolysis of the modified organosilicon polymers, the addition of fillers into preceramic polymers is another choice. Bernardo et al. [10,160-162] fabricated 
SiAlON-based ceramics derived from polysilazane filled with $\mathrm{Al}_{2} \mathrm{O}_{3}, \mathrm{AlN}$, and $\mathrm{Si}_{3} \mathrm{~N}_{4}$ powders beyond $1450{ }^{\circ} \mathrm{C}$, as well as mullite $\left(\mathrm{Al}_{2} \mathrm{O}_{3} \cdot \mathrm{SiO}_{2}\right)$ ceramics from the same polysilazane filled with $\mathrm{Al}_{2} \mathrm{O}_{3}$ nanoparticles. Schlier et al. [163] fabricated $\mathrm{SiOC} / \mathrm{FeSiCr} / \mathrm{SiC}$ composite ceramics, which were derived from polymethylsilsesquioxane with $\mathrm{FeSiCr}$ and $\mathrm{SiC}$ powders as fillers.

Polymer-derived ternary silicon-based ceramics, such as $\mathrm{SiOC}$ and $\mathrm{SiCN}$, have showed great potential for high temperature and structure applications. Especially for foams or composites, there have lots of studies on how to regulate the components or create the porosities with suitable size for practical applications. In biomedical applications, organosilicon polymer-derived porous $\mathrm{SiOC}$ is stable and low toxicity and the SiOC with hierarchical porous structure is promising as a drug carrier.

\section{3 Silicate ceramics}

Silicate ceramics derived from organosilicon polymers containing active fillers have attracted great attentions in the past few years. During the heat treatment process, active fillers are able to react with the pyrolysis products from organosilicon polymers to form silicate ceramics. Compared to traditional methods for fabricating silicate ceramics, the polymer-derived ceramic strategy requires lower ceramization temperature and provides simpler shaping methods. Silicate ceramics are often used as cements, concrete, bioceramics, etc. To date, varieties of silicate ceramics including calcium-based silicate ceramics $\left(\mathrm{CaO} \cdot \mathrm{SiO}_{2}, 2 \mathrm{CaO} \cdot \mathrm{SiO}_{2}\right)$, forsterite $(2 \mathrm{MgO} \cdot \mathrm{SiO})$, mullite $\left(3 \mathrm{Al}_{2} \mathrm{O}_{3} \cdot 2 \mathrm{SiO}_{2}\right)$, zircon $\left(\mathrm{ZrO}_{2} \cdot \mathrm{SiO}_{2}\right)$, willemite $\left(2 \mathrm{ZnO} \cdot \mathrm{SiO}_{2}\right)$, yttrium mono-silicate $\left(\mathrm{Y}_{2} \mathrm{O}_{3} \cdot \mathrm{SiO}_{2}\right)$, and ternary silicates such as akermanite $\left(2 \mathrm{CaO} \cdot \mathrm{MgO} \cdot 2 \mathrm{SiO}_{2}\right)$, diopside $\left(\mathrm{CaO} \cdot \mathrm{MgO} \cdot 2 \mathrm{SiO}_{2}\right), \quad$ hardystonite $\left(2 \mathrm{CaO} \cdot \mathrm{ZnO} \cdot 2 \mathrm{SiO}_{2}\right)$, gehlenite $\left(2 \mathrm{CaO} \cdot \mathrm{Al}_{2} \mathrm{O}_{3} \cdot \mathrm{SiO}_{2}\right)$, cordierite $\left(2 \mathrm{MgO} 2 \mathrm{Al}_{2} \mathrm{O}_{3} \cdot 5 \mathrm{SiO}_{2}\right)$ have been fabricated using organosilicon polymers $[18,90-92,164-170]$. Among them, calcium-based silicate ceramics have been developed for biomedical applications due to their excellent bioactivity [171-173].

Bernardo et al. [73,74,174,175] fabricated porous wollastonite $\left(\mathrm{CaSiO}_{3}\right)$ bioceramics derived from polysiloxanes and calcium sources. The reaction between silica from polysiloxanes and calcium sources results in the formation of $\mathrm{CaSiO}_{3}$ from 1000 to $1200{ }^{\circ} \mathrm{C}$. It demonstrated that the crystallinity of wollastonite bioceramics was influenced by the particle size of calcium sources, and the smaller-sized calcium sources with higher surface area improved the crystallinity. Fiocco et al. [176] fabricated bioactive glasses derived from polysiloxane and active fillers. By adjusting the amounts of active fillers such as calcium carbonate, sodium carbonate, or sodium phosphate dibasic heptahydrate, 45S5 and $58 \mathrm{~S}$ bioactive glasses were successfully fabricated from the reaction between silica and active fillers at $1000{ }^{\circ} \mathrm{C}$. These studies demonstrated that most of silicate bioceramics can be fabricated from organosilicon polymers combining with other sources in a specific ratio. Based on that, varieties of calcium silicate-based bioceramics have been developed by organosilicon polymer-derived ceramic strategy. For example, Zocca et al. [90] and Elsayed et al. [91] fabricated hardystonite $\left(\mathrm{Ca}_{2} \mathrm{ZnSi}_{2} \mathrm{O}_{7}\right)$ bioceramics derived from polysiloxane loaded with $\mathrm{ZnO}$ and $\mathrm{CaCO}_{3}$ active fillers. The desired hardystonite phase was only found sintering in air atmosphere, while sintering in nitrogen produced wollastonite polymorphs, which could be attributed to the carbothermal reduction of the zinc oxide and subsequent evaporation of metallic zinc. Bernardo et al. [164] fabricated akermanite $\left(\mathrm{Ca}_{2} \mathrm{MgSi}_{2} \mathrm{O}_{7}\right)$ bioceramics derived from polysiloxane loaded with $\mathrm{CaCO}_{3}$ and $\mathrm{Mg}(\mathrm{OH})_{2}$ active fillers. With smaller particle size of the active fillers, akermanites with higher crystallinity were obtained over $900{ }^{\circ} \mathrm{C}$.

On the other hand, there also have some studies about organosilicon polymer-derived composites. Bernardo et al. [177,178] fabricated wollastonite/hydroapatite composite bioceramics from polysiloxane loaded with $\mathrm{CaCO}_{3}$ and hydroxyapatite (HA). During sintering, $\mathrm{CaO}$ reacted with silica to form wollastonite phase while hydroapatite was inert. Fiocco et al. [92] fabricated $\mathrm{CaCO}_{3} / \mathrm{SiO}_{2}$ composite bioceramics. Here, $\mathrm{CaCO}_{3}$ powers were used as inert fillers and $\mathrm{SiO}_{2}$ was derived from polysiloxane sintering at $600{ }^{\circ} \mathrm{C}$. Elsayed et al. [93] and Fiocco et al. [166,179,180] fabricated wollastonite/diopside composite bioceramics with a ratio of $1: 1 . \mathrm{CaCO}_{3}$ and $\mathrm{Mg}(\mathrm{OH})_{2}$ were used as active fillers and reacted with polysiloxane at $1100{ }^{\circ} \mathrm{C}$ to form wollastonite and diopside phases. The difference of the sintering atmosphere between air and nitrogen was investigated. It was found that the scaffolds sintered in nitrogen possessed larger pores and thinner struts while the crystal phases were similar. Zocca et al. [94] fabricated wollastonite/bioactive glass composite bioceramics from polysiloxane loaded with $\mathrm{CaCO}_{3}$ filers. As inert filler, AP40 bioactive glass was added, and the findings showed that with a higher amount of 
glasses, the composite bioceramics possessed a higher porosity and smaller shrinkage after ceramization.

As known, porous structure is very important for bioceramics, which facilitates cell migration, nutrient delivery, bone ingrowth, or vascularization. The porosity is closely related to the mechanical strength, and the mechanical strength of the representative organosilicon polymer-derived porous silicate bioceramics by using different pore-making methods have been summarized in Table 3. Among these above-mentioned works, the addition of foaming agents in starting materials is a common method to fabricate porous calcium silicate-based bioceramics. The foaming agents include sodium phosphate dibasic heptahydrate $\left(\mathrm{Na}_{2} \mathrm{HPO}_{4} \cdot 7 \mathrm{H}_{2} \mathrm{O}\right)$, borax $\left(\mathrm{Na}_{2} \mathrm{~B}_{4} \mathrm{O}_{7} \cdot 10 \mathrm{H}_{2} \mathrm{O}\right)$, sodium borate, dicarbamoylhydrazine (DCH), polymethyl methacrylate (PMMA), Pluronic P123, hydrazine derivative, etc., which has been summarized in Table 3. For instance, Fiocco et al. [180] and de Castro Juraski et al. [181] fabricated wollastonite-diopside $\left(\mathrm{CaSiO}_{3}-\mathrm{CaMgSi}_{2} \mathrm{O}_{6}\right)$ porous bioceramics by using sodium phosphate dibasic heptahydrate $\left(\mathrm{Na}_{2} \mathrm{HPO}_{4} \cdot 7 \mathrm{H}_{2} \mathrm{O}\right)$ as a foaming agent, the final bioceramics processed an open porosity ( $>75 \%)$ and a crushing strength $(<3.8 \mathrm{MPa})$. When borax was used as a foaming agent, wollastonite-diopside ceramics had a higher open porosity ( $>80 \%$ ) and a compressive strength $(<2 \mathrm{MPa})$ [168], while a higher compressive strength $(>20 \mathrm{MPa})$ with a residual open porosity $(65 \%)$ could be obtained using sodium borate [182]. Similarly, dicarbamoylhydrazine foaming agent was used to fabricate organosilicon polymer-derived wollastonite-hydroxycarbonate apatite ceramics, and the final ceramics processed good interconnectivity and uniform pore size $(500 \mu \mathrm{m})$ [178]. However, the over-reliance on the structure and property of the foaming agents limits the controllable fabrication, and even needs a one more step for removing the foaming agents. Nowadays, 3D printing technique as an efficient method has been proposed and is able to create designed pore structures for the polymer-derived bioceramics.

The organosilicon polymer-derived silicate-based ceramics facilitate the shaping process and the component of bioceramics can be easily controlled. To date, many studies were emphasized on the bioactivity of the calcium-based silicate bioceramics due to their ability of inducing the formation of hydroxyapatite layer and regulating the cell behaviors. As known, different elements induce different cell performances or immune reaction, leading to a signal pathway to regulate new bone formation, and it is easy to change or incorporate effective elements into organosilicon polymer-derived silicate bioceramics. Thus, some works further explored the bioactivity of organosilicon polymer-derived calcium silicate ceramics $[94,168,176,178-181]$. Also, human osteoblast cells and fibroblast cells were used to evaluate the cell compatibility for those wollastonite/hydroapatite, wollastonite/diopside, wollastonite/bioactive glass composite bioceramics. All these composite ceramics showed good bioactivity and benefited for cell adhesion, proliferation and differentiation.

Table 3 Mechanical strength of the representative organosilicon polymer-derived porous silicate bioceramics by using different methods

\begin{tabular}{|c|c|c|c|c|c|}
\hline Pore-making method & $\begin{array}{l}\text { Organosilicon } \\
\text { polymer (fillers) }\end{array}$ & Silicate bioceramics & $\begin{array}{l}\text { Maximal } \\
\text { porosity }(\%)\end{array}$ & $\begin{array}{l}\text { Maximal mechanical } \\
\text { strength (MPa) }\end{array}$ & Reference \\
\hline $\begin{array}{c}\text { Foaming agents } \\
\text { (polymethyl methacrylate) }\end{array}$ & Polysiloxane $\left(\mathrm{CaCO}_{3}\right)$ & $\mathrm{CaSiO}_{3}$ & 81 & Crushing strength: 9.6 & {$[74,177]$} \\
\hline $\begin{array}{l}\text { Foaming agents (sodium phosphate } \\
\text { dibasic heptahydrate) }\end{array}$ & $\begin{array}{c}\text { Polysiloxane } \\
\left(\mathrm{CaCO}_{3}, \mathrm{Mg}(\mathrm{OH})_{2}\right)\end{array}$ & $\mathrm{CaSiO}_{3} / \mathrm{CaMgSi}_{2} \mathrm{O}_{6}$ & 79 & Crushing strength: 3.8 & {$[180,181]$} \\
\hline Foaming agents (borax) & $\begin{array}{c}\text { Polysiloxane } \\
\left(\mathrm{CaCO}_{3}, \mathrm{Mg}(\mathrm{OH})_{2}\right)\end{array}$ & $\mathrm{Ca}_{2} \mathrm{MgSi}_{2} \mathrm{O}_{7}$ & 72 & Crushing strength: 5.5 & {$[164]$} \\
\hline Foaming agents (sodium borate) & $\begin{array}{c}\text { Polysiloxane } \\
\left(\mathrm{CaCO}_{3}, \mathrm{Mg}(\mathrm{OH})_{2}\right)\end{array}$ & $\begin{array}{l}\mathrm{CaSiO}_{3} / \mathrm{CaMgSi}_{2} \mathrm{O}_{6} / \\
\mathrm{G} 20 \mathrm{CaII} \text { glass }\end{array}$ & 77 & Crushing strength: 6.5 & {$[166]$} \\
\hline $\begin{array}{c}\text { Foaming agents } \\
\text { (dicarbamoylhydrazine) }\end{array}$ & $\begin{array}{c}\text { Polysiloxane } \\
\left(\mathrm{CaCO}_{3}, \mathrm{Ca}_{3}\left(\mathrm{PO}_{4}\right)_{2}\right)\end{array}$ & 58S Bioactive glass & 79 & Crushing strength: 5.6 & {$[176]$} \\
\hline $\begin{array}{c}\text { Foaming agents } \\
\text { (hydrazine derivative) }\end{array}$ & Polysiloxane $\left(\mathrm{CaCO}_{3}, \mathrm{ZnO}\right)$ & $\mathrm{Ca}_{2} \mathrm{ZnSi}_{2} \mathrm{O}_{7}$ & 81 & Compressive strength: 2.1 & {$[170]$} \\
\hline $3 \mathrm{D}$ printing & Polysiloxane $\left(\mathrm{CaCO}_{3}, \mathrm{ZnO}\right)$ & $\mathrm{Ca}_{2} \mathrm{ZnSi}_{2} \mathrm{O}_{7}$ & 76 & Compressive strength: 2.5 & {$[90,91]$} \\
\hline $3 \mathrm{D}$ printing & Polysiloxane $\left(\mathrm{CaCO}_{3}\right)$ & $\mathrm{CaCO}_{3} / \mathrm{SiO}_{2}$ & 64 & Compressive strength: 5.5 & {$[92]$} \\
\hline $3 \mathrm{D}$ printing & $\begin{array}{c}\text { Polysiloxane } \\
\left(\mathrm{CaCO}_{3}, \mathrm{Mg}(\mathrm{OH})_{2}\right)\end{array}$ & $\mathrm{CaSiO}_{3} / \mathrm{CaMgSi}_{2} \mathrm{O}_{6}$ & 76 & Compressive strength: 4.9 & [93] \\
\hline $3 \mathrm{D}$ printing & Polysiloxane $\left(\mathrm{CaCO}_{3}, \mathrm{ZrO}_{2}\right)$ & $\mathrm{Ca}_{2} \mathrm{SiO}_{4} / \mathrm{ZrO}_{2}$ & 74 & Compressive strength: 5.5 & [184] \\
\hline
\end{tabular}


Recently, our group has successfully fabricated 3D-printed $\beta-\mathrm{Ca}_{2} \mathrm{SiO}_{4}$ scaffolds from preceramic resin loaded with $\mathrm{CaCO}_{3}$ active fillers [183]. $\beta-\mathrm{Ca}_{2} \mathrm{SiO}_{4}$ phase could be formed over $900{ }^{\circ} \mathrm{C}$ sintering and the crystallinity of the ceramic scaffolds increased with increasing the sintering temperature. The obtained $\beta-\mathrm{Ca}_{2} \mathrm{SiO}_{4}$ scaffolds maintained porous structures with uniform interconnected macropores (ca. $400 \mu \mathrm{m}$ ), high porosity $(>78 \%$ ), and a maximum compressive strength (ca. $5.2 \mathrm{MPa}$ ). Moreover, the $\beta-\mathrm{Ca}_{2} \mathrm{SiO}_{4}$ scaffolds exhibited excellent apatite mineralization ability in stimulated body fluid (SBF). The in vitro experiments showed that the cell adhesion, proliferation, alkaline phosphatase activity, and osteogenic-related gene expression of rat bone mesenchymal stem cells (rBMSCs) were stimulated for the $\beta-\mathrm{Ca}_{2} \mathrm{SiO}_{4}$ scaffolds with higher sintering temperature (Fig. 7). However, the mechanical property of calcium-based bioceramics is still not desirable for practice applications, and high dissolution rate will lead to a weak alkali environment. To regulate the degradation rate and create a more stable microenvironment for cells, and thereby eventually promote new bone formation, $\mathrm{ZrO}_{2}$ as an inert filler was incorporated into $\beta-\mathrm{Ca}_{2} \mathrm{SiO}_{4}$ ceramics [184]. The
$\mathrm{ZrO}_{2}$ incorporation significantly enhanced the compressive strength $(5.5 \mathrm{MPa})$ compared to $\beta-\mathrm{Ca}_{2} \mathrm{SiO}_{4}$ scaffolds, and stimulated the cell proliferation and differentiation of osteoblasts. Importantly, in vivo results indicated that the $\mathrm{ZrO}_{2}$-incorporated $\beta-\mathrm{Ca}_{2} \mathrm{SiO}_{4}$ scaffolds improved osteogenic capacity (Fig. 8) and it would be a promising candidate for bone tissue engineering.

Polymer-derived silicate ceramics are varied, and their components can be easily adjusted by adding different fillers, which greatly promotes the organosilicon polymer-derived strategy for fabricating bioceramics in bone regeneration. Recently, calcium-based polymerderived bioceramics have aroused greatly attentions, and in vitro and in vivo studies proved these bioceramics were able to promote new bone formation.

\section{Conclusions and perspectives}

Traditional methods to fabricate silicon-based ceramics are often high-energy consumption and difficult for shaping. Polymer-derived ceramic route has been developed and is able to overcome these limitations to some extent. To fabricate silicon-based ceramics derived

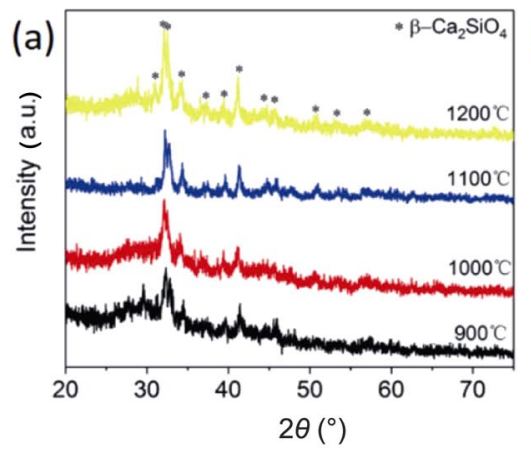

(d)

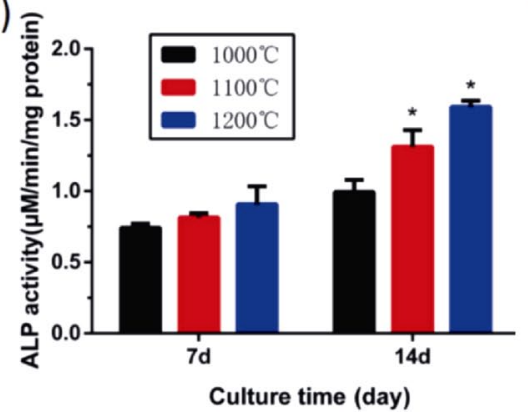

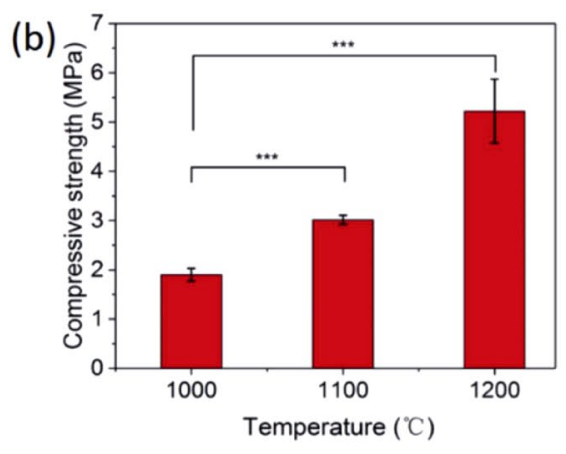

(e)

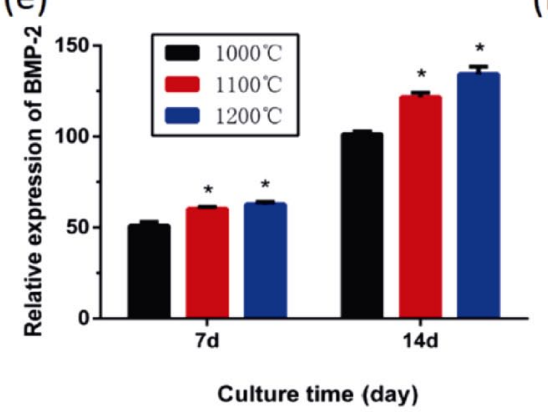

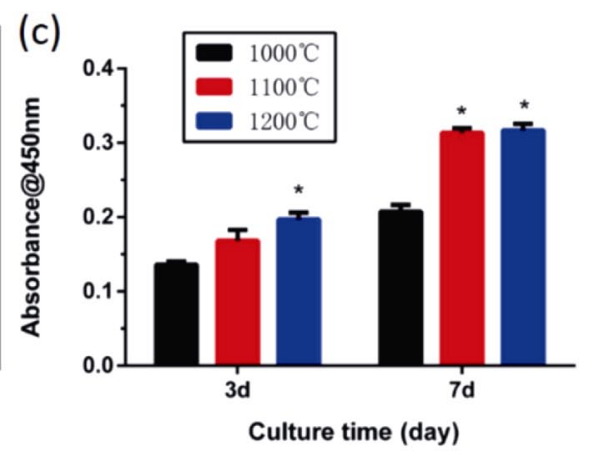

(f)

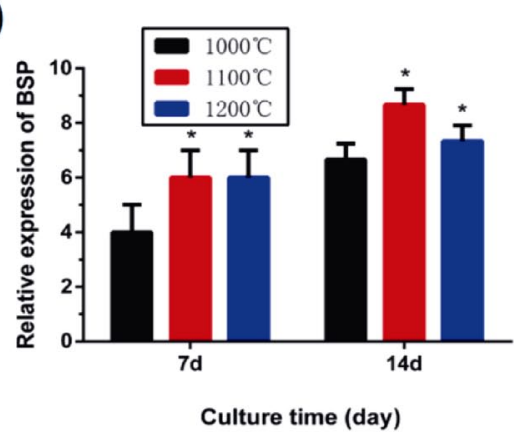

Fig. 7 (a) XRD patterns and (b) compressive strength of $\beta-\mathrm{Ca}_{2} \mathrm{SiO}_{4}$ scaffolds sintered at different temperature for $5 \mathrm{~h}$. (c) Quantitative analysis of the proliferation of rBMSCs cultured on $\beta-\mathrm{Ca}_{2} \mathrm{SiO}_{4}$ scaffolds for 3 and 7 days. (d) ALP activity of rBMSCs cultured for 7 and 14 days on $\beta-\mathrm{Ca}_{2} \mathrm{SiO}_{4}$ scaffolds for 7 and 14 days. Osteogenic expression of (e) BMP-2 and (f) BSP for rBMSCs cultured on $\beta-\mathrm{Ca}_{2} \mathrm{SiO}_{4}$ scaffolds by qRT-PCR analysis after 7 and 14 days. Reproduced with permission from Ref. [183], C The Author(s) 2018. 

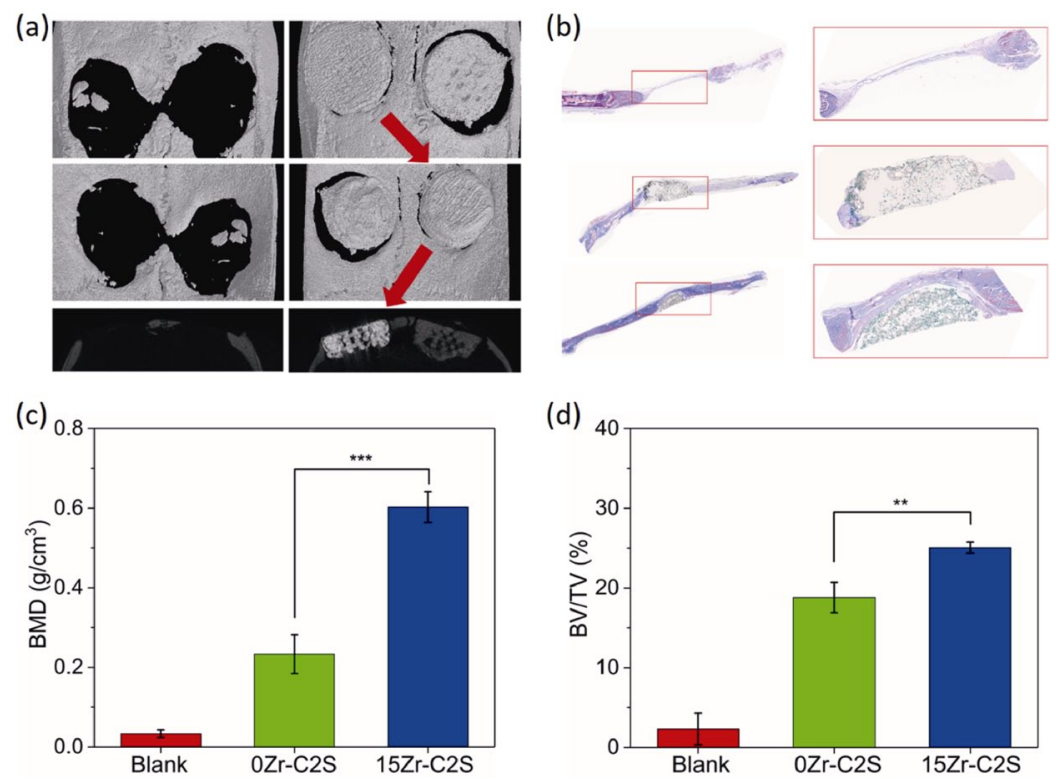

Fig. 8 (a) Micro-CT evaluation, blank group (left), $\beta-\mathrm{Ca}_{2} \mathrm{SiO}_{4}$ scaffolds (right, dark area), and $\mathrm{ZrO}_{2}$ incorporated $\beta-\mathrm{Ca}_{2} \mathrm{SiO}_{4}$ scaffolds (right, light area), and (b) histological analysis of the repaired skulls at 8-week post-implantation (top: blank group; middle: $\beta-\mathrm{Ca}_{2} \mathrm{SiO}_{4}$ scaffolds; bottom: $\mathrm{ZrO}_{2}$ incorporated $\beta-\mathrm{Ca}_{2} \mathrm{SiO}_{4}$ scaffolds). Quantitative analysis of (c) BMD and (d) BV/TV. Reproduced with permission from Ref. [184], (C) Journal of Inorganic Materials 2019.

from organosilicon polymers, the preparation of the starting organosilicon precursors, shaping, cross-linking of the organosilicon precursors and sintering are four main processes, which determine the compositions and properties of the final ceramics. However, polymer-derived ceramic route to fabricate silicon-based ceramics often suffers from the large shrinkage during a pyrolysis and many cracks occur in the final ceramics. Although the shrinkage and cracks can be solved by the introduction of fillers, the composition of the final ceramics cannot be controlled precisely, especially the carbon in organosilicon polymers.

To construct silicon-based ceramics with controllable structures, combining polymer-derived ceramic route with $3 \mathrm{D}$ printing technique is extremely promising. Using $3 \mathrm{D}$ printing technique, starting organosilicon polymers are easily shaped into controllable complex structures, which can be maintained after a pyrolysis process to obtain final ceramics. Moreover, preceramic polymers are able to provide a liquid phase during the pyrolysis to decrease the sintering temperature. Nowadays, many silicate ceramics have been successfully fabricated by 3D printing of organosilicon polymers. In biomedical applications, organosilicon polymer-derived non-oxide ceramics (SiOC) have been studied on their drug delivery ability and its possibility on blood contact applications, while other organosilicon polymer-derived non-oxide ceramics including $\mathrm{SiC}, \mathrm{Si}_{3} \mathrm{~N}_{4}$, and $\mathrm{SiCN}$ have shown great potentials. Organosilicon polymer-derived silicate bioceramics are promising for bone tissue engineering, because the strategy facilitates the shaping process and the component of bioceramics can be easily controlled. Therefore, the development of novel preceramic polymers for fabricating other functional ceramics should be expected, such as borate ceramics, phosphate ceramics, and the 3D printing technique further endow the precious and controllable structures to ceramics in the future.

\section{Acknowledgements}

The authors gratefully acknowledge the support by grants from the National Natural Science Foundation of China (Grant No. 51872185), the Science and Technology Commission of Shanghai Municipality (Grant No. 17060502400), and the University of Shanghai for Science and Technology (Grant No. 2017KJFZ010).

\section{References}

[1] Zhao ZG, Li KZ, Li W, et al. Preparation, ablation behavior and mechanism of $\mathrm{C} / \mathrm{C}-\mathrm{ZrC}-\mathrm{SiC}$ and $\mathrm{C} / \mathrm{C}-\mathrm{SiC}$ composites. Ceram Int 2018, 44: 7481-7490.

[2] Du B, Hong CQ, Zhang $\mathrm{XH}$, et al. Preparation and mechanical behaviors of SiOC-modified carbon-bonded carbon fiber composite with in situ growth of three-dimensional 
SiC nanowires. J Eur Ceram Soc 2018, 38: 2272-2278.

[3] Zhang LL, Pei LN, Li HJ, et al. Preparation and characterization of $\mathrm{Na}$ and $\mathrm{F}$ co-doped hydroxyapatite coating reinforced by carbon nanotubes and $\mathrm{SiC}$ nanoparticles. Mater Lett 2018, 218: 161-164.

[4] Idesaki A, Colombo P. Synthesis of a Ni-containing porous SiOC material from polyphenylmethylsiloxane by a direct foaming technique. Adv Eng Mater 2012, 14: 1116-1122.

[5] Eckel ZC, Zhou C, Martin JH, et al. Additive manufacturing of polymer-derived ceramics. Science 2016, 351: 58-62.

[6] Sun SY, Wang Q, Ge YY, et al. Synthesis of well-dispersed columnar $\mathrm{Si}_{3} \mathrm{~N}_{4}$ using carbothermal reduction-nitridation method. Powder Technol 2018, 331: 322-325.

[7] Chen AN, Wu JM, Han LX, et al. Preparation of $\mathrm{Si}_{3} \mathrm{~N}_{4}$ foams by DCC method via dispersant reaction combined with protein-gelling. J Alloys Compd 2018, 745: 262-270.

[8] Han L, Wang JK, Li FL, et al. Low-temperature preparation of $\mathrm{Si}_{3} \mathrm{~N}_{4}$ whiskers bonded/reinforced $\mathrm{SiC}$ porous ceramics via foam-gelcasting combined with catalytic nitridation. $J$ Eur Ceram Soc 2018, 38: 1210-1218.

[9] Nguyen VL, Zera E, Perolo A, et al. Synthesis and characterization of polymer-derived $\mathrm{SiCN}$ aerogel. $J$ Eur Ceram Soc 2015, 35: 3295-3302.

[10] Bernardo E, Parcianello G, Colombo P, et al. SiAlON ceramics from preceramic polymers and nano-sized fillers: Application in ceramic joining. J Eur Ceram Soc 2012, 32: 1329-1335.

[11] Qing ZJ, Zhou WZ, Xia WJ, et al. Crystallization kinetics, sintering, microstructure, and properties of low temperature co-fired magnesium aluminum silicate glass-ceramic. $J$ Non-Cryst Solids 2018, 486: 14-18.

[12] Yu QQ, Han YM, Wang XC, et al. Copper silicate hollow microspheres-incorporated scaffolds for chemo-photothermal therapy of melanoma and tissue healing. ACS Nano 2018, 12: 2695-2707.

[13] Xu SF, Lin KL, Wang Z, et al. Reconstruction of calvarial defect of rabbits using porous calcium silicate bioactive ceramics. Biomaterials 2008, 29: 2588-2596.

[14] Pavarajarn V, Precharyutasin R, Praserthdam P. Synthesis of silicon nitride fibers by the carbothermal reduction and nitridation of rice husk ash. J Am Ceram Soc 2010, 93: 973-979.

[15] Arcos D, Vallet-Regí M. Sol-gel silica-based biomaterials and bone tissue regeneration. Acta Biomater 2010, 6: 2874-2888.

[16] Colombo P, Bernardo E, Parcianello G. Multifunctional advanced ceramics from preceramic polymers and nano-sized active fillers. J Eur Ceram Soc 2013, 33: 453-469.

[17] Ionescu E, Kleebe HJ, Riedel R. Silicon-containing polymer-derived ceramic nanocomposites (PDC-NCs): Preparative approaches and properties. Chem Soc Rev 2012, 41: 5032-5052.

[18] Bernardo E, Fiocco L, Parcianello G, et al. Advanced ceramics from preceramic polymers modified at the nano-scale: A review. Materials 2014, 7: 1927-1956.
[19] Bernard S, Miele P. Polymer-derived boron nitride: A review on the chemistry, shaping and ceramic conversion of borazine derivatives. Materials 2014, 7: 7436-7459.

[20] Gmeiner R, Deisinger U, Schönherr J, et al. Additive manufacturing of bioactive glasses and silicate bioceramics. J Ceram Sci Tech 2015, 06: 75-86.

[21] Riedel R, Mera G, Hauser R, et al. Silicon-based polymer-derived ceramics: Synthesis properties and applications-A review. J Ceram Soc Jpn 2006, 114: 425-444.

[22] Colombo P, Mera G, Riedel R, et al. Polymer-derived ceramics: 40 years of research and innovation in advanced ceramics. J Am Ceram Soc 2010, 93: 1805-1837

[23] Zhu M, Huang T, Du X, et al. Progress of the 3D printing technology for biomaterials. Journal of University of Shanghai for Science and Technology 2017, 39: 473-489. (in Chinese)

[24] Xin C, Qi X, Zhu M, et al. Hydroxyapatite whisker-reinforced composite scaffolds through 3D printing for bone repair. $J$ Inorg Mater 2017, 32: 837-844. (in Chinese)

[25] Du XY, Fu SY, Zhu YF. 3D printing of ceramic-based scaffolds for bone tissue engineering: An overview. $J$ Mater Chem B 2018, 6: 4397-4412.

[26] Pei P, Tian ZF, Zhu YF. 3D printed mesoporous bioactive glass/metal-organic framework scaffolds with antitubercular drug delivery. Microporous Mesoporous Mater 2018, 272: 24-30.

[27] Jones RG, Holder SJ. High-yield controlled syntheses of polysilanes by the Wurtz-type reductive coupling reaction. Polym Int 2006, 55: 711-718.

[28] Kashimura S, Tane Y, Ishifune M, et al. Practical method for the synthesis of polysilanes using $\mathrm{Mg}$ and Lewis acid system. Tetrahedron Lett 2008, 49: 269-271.

[29] Krempner C. Polysilane dendrimers. Polymers 2012, 4: 408-447.

[30] Lodhe M, Babu N, Selvam A, et al. Synthesis and characterization of high ceramic yield polycarbosilane precursor for SiC. J Adv Ceram 2015, 4: 307-311.

[31] Chen JX, He GM, Liao ZN, et al. Control of structure formation of polycarbosilane synthesized from polydimethylsilane by Kumada rearrangement. J Appl Polym Sci 2008, 108: 3114-3121.

[32] Cheng XZ, Xie ZF, Song YC, et al. Structure and properties of polycarbosilane synthesized from polydimethylsilane under high pressure. J Appl Polym Sci 2006, 99: 1188-1194.

[33] Wang GD, Song YC. Enhancing the yield of polycarbosilane synthesis via recycling of liquid by-product at atmospheric pressure. Ceram Int 2018, 44: 6474-6478.

[34] He LJ, Zhang ZB, Yang XG, et al. Liquid polycarbosilanes: Synthesis and evaluation as precursors for $\mathrm{SiC}$ ceramic. Polym Int 2015, 64: 979-985.

[35] Li HB, Zhang LT, Cheng LF, et al. Polymer-ceramic conversion of a highly branched liquid polycarbosilane for SiC-based ceramics. J Mater Sci 2008, 43: 2806-2811. 
[36] Ma Y, Wang S, Chen ZH. Raman spectroscopy studies of the high-temperature evolution of the free carbon phase in polycarbosilane derived SiC ceramics. Ceram Int 2010, 36: 2455-2459.

[37] Wang YC, Xiao P, Zhou W, et al. Microstructures, dielectric response and microwave absorption properties of polycarbosilane derived SiC powders. Ceram Int 2018, 44: 3606-3613.

[38] Long X, Shao CW, Wang J, et al. Synthesis of soluble and meltable pre-ceramic polymers for $\mathrm{Zr}$-containing ceramic nanocomposites. Appl Organometal Chem 2018, 32: e3942.

[39] Shukla SK, Tiwari RK, Ranjan A, et al. Some thermal studies of polysilanes and polycarbosilanes. Thermochim Acta 2004, 424: 209-217.

[40] Gardelle B, Duquesne S, Vu C, et al. Thermal degradation and fire performance of polysilazane-based coatings. Thermochim Acta 2011, 519: 28-37.

[41] Bakumov V, Gueinzius K, Hermann C, et al. Polysilazane-derived antibacterial silver-ceramic nanocomposites. J Eur Ceram Soc 2007, 27: 3287-3292.

[42] Vakifahmetoglu C, Menapace I, Hirsch A, et al. Highly porous macro- and micro-cellular ceramics from a polysilazane precursor. Ceram Int 2009, 35: 3281-3290.

[43] Günthner M, Kraus T, Dierdorf A, et al. Advanced coatings on the basis of $\mathrm{Si}(\mathrm{C}) \mathrm{N}$ precursors for protection of steel against oxidation. J Eur Ceram Soc 2009, 29: 2061-2068.

[44] Günthner M, Wang KS, Bordia RK, et al. Conversion behaviour and resulting mechanical properties of polysilazane-based coatings. J Eur Ceram Soc 2012, 32: 1883-1892.

[45] Chiu HT, Sukachonmakul T, Kuo MT, et al. Surface modification of aluminum nitride by polysilazane and its polymer-derived amorphous silicon oxycarbide ceramic for the enhancement of thermal conductivity in silicone rubber composite. Appl Surf Sci 2014, 292: 928-936.

[46] Sarkar S, Zou JH, Liu JH, et al. Polymer-derived ceramic composite fibers with aligned pristine multiwalled carbon nanotubes. ACS Appl Mater Interfaces 2010, 2: 1150-1156.

[47] Hörz M, Zern A, Berger F, et al. Novel polysilazanes as precursors for silicon nitride/silicon carbide composites without "free" carbon. J Eur Ceram Soc 2005, 25: 99-110.

[48] Kroke E, Li YL, Konetschny C, et al. Silazane derived ceramics and related materials. Mat Sci Eng R Rep 2000, 26: 97-199.

[49] Qi GJ, Zhang CR, Hu HF, et al. Preparation of three-dimensional silica fiber reinforced silicon nitride composites using perhydropolysilazane as precursor. Mater Lett 2005, 59: 3256-3258.

[50] Sun F, Jiang SL. Synthesis and characterization of photosensitive polysiloxane. Nucl Instruments Methods Phys Res Sect B Beam Interactions Mater Atoms 2007, 254: 125-130.

[51] Li Z, Li J, Qin J, et al. Synthesis and characterization of polysiloxanes containing carbazolyl and sulfonyl-indole based chromophore as side chains. Polymer 2005, 46: 363-368.

[52] Narisawa M. Silicone resin applications for ceramic precursors and composites. Materials 2010, 3: 3518-3536.

[53] Boehm P, Mondeshki M, Frey H. Polysiloxane-backbone block copolymers in a one-pot synthesis: A silicone platform for facile functionalization. Macromol Rapid Commun 2012, 33: 1861-1867.

[54] Chojnowski J, Cypryk M, Kurjata J. Organic polysilanes interrupted by heteroatoms. Prog Polym Sci 2003, 28: 691-728.

[55] Zhou WJ, Yang H, Guo XZ, et al. Thermal degradation behaviors of some branched and linear polysiloxanes. Polym Degrad Stab 2006, 91: 1471-1475.

[56] Soraru GD. Silicon oxycarbide glasses from gels. J Sol-Gel Sci Technol 1994, 2: 843-848.

[57] Widgeon S, Mera G, Gao Y, et al. Nanostructure and energetics of carbon-rich $\mathrm{SiCN}$ ceramics derived from polysilylcarbodiimides: Role of the nanodomain interfaces. Chem Mater 2012, 24: 1181-1191.

[58] Mera G, Riedel R, Poli F, et al. Carbon-rich SiCN ceramics derived from phenyl-containing poly(silylcarbodiimides). J Eur Ceram Soc 2009, 29: 2873-2883.

[59] Iwamoto Y, Völger W, Kroke E, et al. Crystallization behavior of amorphous silicon carbonitride ceramics derived from organometallic precursors. J Am Ceram Soc 2004, 84: 2170-2178.

[60] Oishi M, Minakawa M, Imae I, et al. Synthesis and characterization of optically active hyperbranched poly (carbosiloxane)s. Macromolecules 2002, 35: 4938-4945.

[61] Sacarescu L, Capmare E, Ardeleanu R, et al. Hyperbranched polycyclocarbosiloxane. Eur Polym $J$ 2002, 38: 983-987.

[62] Hu J, Carver PI, Meier DJ, et al. Hyperbranched polycarbosiloxanes and polycarbosilanes via bimolecular non-linear hydrosilylation polymerization. Polymer 2012, 53: 5459-5468.

[63] Gao Y, Mera G, Nguyen $\mathrm{H}$, et al. Processing route dramatically influencing the nanostructure of carbon-rich $\mathrm{SiCN}$ and SiBCN polymer-derived ceramics. Part I: Low temperature thermal transformation. J Eur Ceram Soc 2012, 32: 1857-1866.

[64] Widgeon S, Mera G, Gao Y, et al. Effect of precursor on speciation and nanostructure of SiBCN polymer-derived ceramics. J Am Ceram Soc 2013, 96: 1651-1659.

[65] Zhang ZB, Zeng F, Han JJ, et al. Synthesis and characterization of a new liquid polymer precursor for Si-B-C-N ceramics. J Mater Sci 2011, 46: 5940-5947.

[66] Whittell GR, Manners I. Metallopolymers: New multifunctional materials. Adv Mater 2007, 19: 3439-3468.

[67] Whittell GR, Hager MD, Schubert US, et al. Functional soft materials from metallopolymers and metallosupramolecular polymers. Nat Mater 2011, 10: 176-188.

[68] Cai T, Qiu WF, Liu D, et al. Synthesis of soluble poly-yne 
polymers containing zirconium and silicon and corresponding conversion to nanosized $\mathrm{ZrC} / \mathrm{SiC}$ composite ceramics. Dalton Trans 2013, 42: 4285-4290.

[69] Yu ZJ, Yang L, Min H, et al. Single-source-precursor synthesis of high temperature stable $\mathrm{SiC} / \mathrm{C} / \mathrm{Fe}$ nanocomposites from a processable hyperbranched polyferrocenylcarbosilane with high ceramic yield. $J$ Mater Chem C 2014, 2: 1057-1067.

[70] Gou Y, Tong X, Zhang Q, et al. The preparation and characterization of polymer-derived $\mathrm{Fe} / \mathrm{Si} / \mathrm{C}$ magnetoceramics. Ceram Int 2016, 42: 681-689.

[71] Balan C, Riedel R. Rheological investigations of a polymeric precursor for ceramic materials: Experiments and theoretical modeling. J Optoelectro Adv Mater 2006, 8: 561-567.

[72] Harshe R, Balan C, Riedel R. Amorphous Si(Al)OC ceramic from polysiloxanes: Bulk ceramic processing, crystallization behavior and applications. J Eur Ceram Soc 2004, 24: 3471-3482.

[73] Bernardo E, Colombo P, Dainese E, et al. Novel 3D wollastonite-based scaffolds from preceramic polymers containing micro- and nano-sized reactive particles. $A d v$ Eng Mater 2012, 14: 269-274.

[74] Bernardo E, Parcianello G, Colombo P, et al. Wollastonite foams from an extruded preceramic polymer mixed with $\mathrm{CaCO}_{3}$ microparticles assisted by supercritical carbon dioxide. Adv Eng Mater 2013, 15: 60-65.

[75] Zhang JH, Zhao SC, Zhu M, et al. 3D-printed magnetic $\mathrm{Fe}_{3} \mathrm{O}_{4} / \mathrm{MBG} / \mathrm{PCL}$ composite scaffolds with multifunctionality of bone regeneration, local anticancer drug delivery and hyperthermia. J Mater Chem B 2014, 2: 7583-7595.

[76] Pei P, Wei DX, Zhu M, et al. The effect of calcium sulfate incorporation on physiochemical and biological properties of 3D-printed mesoporous calcium silicate cement scaffolds. Microporous Mesoporous Mater 2017, 241: 11-20.

[77] Du XY, Yu B, Pei P, et al. 3D printing of pearl/ $/ \mathrm{CaSO}_{4}$ composite scaffolds for bone regeneration. J Mater Chem B 2018, 6: 499-509.

[78] Pei P, Qi X, Du XY, et al. Three-dimensional printing of tricalcium silicate/mesoporous bioactive glass cement scaffolds for bone regeneration. J Mater Chem B 2016, 4: $7452-7463$.

[79] Zhang JH, Zhao SC, Zhu YF, et al. Three-dimensional printing of strontium-containing mesoporous bioactive glass scaffolds for bone regeneration. Acta Biomater 2014, 10: 2269-2281.

[80] Zhang JH, Zhu YF. Synthesis and characterization of $\mathrm{CeO}_{2}$-incorporated mesoporous calcium-silicate materials. Microporous Mesoporous Mater 2014, 197: 244-251.

[81] Qi X, Pei P, Zhu M, et al. Three dimensional printing of calcium sulfate and mesoporous bioactive glass scaffolds for improving bone regeneration in vitro and in vivo. Sci Rep 2017, 7: 42556.

[82] Yu B, Pei P, Yu BQ, et al. Enhance the bioactivity and osseointegration of the polyethylene-terephthalate-based artificial ligament via poly(dopamine) coating with mesoporous bioactive glass. Adv Eng Mater 2017, 19: 1600708.

[83] Li S, Duan WY, Zhao T, et al. The fabrication of SiBCN ceramic components from preceramic polymers by digital light processing (DLP) 3D printing technology. $J$ Eur Ceram Soc 2018, 38: 4597-4603.

[84] Zanchetta E, Cattaldo M, Franchin G, et al. Stereolithography of SiOC ceramic microcomponents. Adv Mater 2016, 28: 370-376.

[85] $\mathrm{Fu} \mathrm{YL}, \mathrm{Xu} \mathrm{G}$, Chen ZW, et al. Multiple metals doped polymer-derived SiOC ceramics for $3 \mathrm{D}$ printing. Ceram Int 2018, 44: 11030-11038.

[86] De Hazan Y, Penner D. SiC and SiOC ceramic articles produced by stereolithography of acrylate modified polycarbosilane systems. J Eur Ceram Soc 2017, 37: 5205-5212.

[87] Zocca A, Gomes CM, Staude A, et al. SiOC ceramics with ordered porosity by $3 \mathrm{D}$-printing of a preceramic polymer. $J$ Mater Res 2013, 28: 2243-2252.

[88] Chen HH, Wang XF, Xue FD, et al. 3D printing of SiC ceramic: Direct ink writing with a solution of preceramic polymers. J Eur Ceram Soc 2018, 38: 5294-5300.

[89] Pierin G, Grotta C, Colombo P, et al. Direct Ink Writing of micrometric SiOC ceramic structures using a preceramic polymer. J Eur Ceram Soc 2016, 36: 1589-1594.

[90] Zocca A, Franchin G, Elsayed H, et al. Direct ink writing of a preceramic polymer and fillers to produce hardystonite $\left(\mathrm{Ca}_{2} \mathrm{ZnSi}_{2} \mathrm{O}_{7}\right)$ bioceramic scaffolds. J Am Ceram Soc 2016, 99: 1960-1967.

[91] Elsayed H, Sinico M, Secco M, et al. B-doped hardystonite bioceramics from preceramic polymers and fillers: Synthesis and application to foams and 3D-printed scaffolds. J Eur Ceram Soc 2017, 37: 1757-1767.

[92] Fiocco L, Elsayed H, Badocco D, et al. Direct ink writing of silica-bonded calcite scaffolds from preceramic polymers and fillers. Biofabrication 2017, 9: 025012.

[93] Elsayed H, Colombo P, Bernardo E. Direct ink writing of wollastonite-diopside glass-ceramic scaffolds from a silicone resin and engineered fillers. J Eur Ceram Soc 2017, 37: 4187-4195.

[94] Zocca A, Elsayed H, Bernardo E, et al. 3D-printed silicate porous bioceramics using a non-sacrificial preceramic polymer binder. Biofabrication 2015, 7: 025008.

[95] Mishra MK, Kumar S, Ranjan A, et al. Processing, properties and microstructure of $\mathrm{SiC}$ foam derived from epoxy-modified polycarbosilane. Ceram Int 2018, 44: 1859-1867.

[96] Ma Y, Wang S, Chen ZH. Effects of high-temperature annealing on the microstructures and mechanical properties of $\mathrm{Cf} / \mathrm{SiC}$ composites using polycarbosilane. Mat Sci Eng A 2011, 528: 3069-3072.

[97] Liu J, Qiao YL, Zhang P, et al. Synthesis of SiC ceramics from polysilazane by laser pyrolysis. Surf Coat Technol 2017, 321: 491-495. 
[98] Yan J, Wang AJ, Kim DP. Preparation of ordered mesoporous $\mathrm{SiC}$ from preceramic polymer templated by nanoporous silica. J Phys Chem B 2006, 110: 5429-5433.

[99] Eick BM, Youngblood JP. SiC nanofibers by pyrolysis of electrospun preceramic polymers. J Mater Sci 2009, 44: 160-165.

[100] Boakye EE, Mogilevsky P, Parthasarathy TA, et al. Monazite coatings on SiC fibers I: Fiber strength and thermal stability. J Am Ceram Soc 2006, 89: 3475-3480.

[101] $\mathrm{Hu} \mathrm{TJ}, \mathrm{Li} \mathrm{XD}, \mathrm{Li} \mathrm{GY}$, et al. SiC fibers with controllable thickness of carbon layer prepared directly by preceramic polymer pyrolysis routes. Mat Sci Eng B 2011, 176: 706-710.

[102] Flores O, Bordia RK, Nestler D, et al. Ceramic fibers based on $\mathrm{SiC}$ and $\mathrm{SiCN}$ systems: Current research, development, and commercial status. Adv Eng Mater 2014, 16: 621-636.

[103] Bunsell AR, Piant A. A review of the development of three generations of small diameter silicon carbide fibres. $J$ Mater Sci 2006, 41: 823-839.

[104] Mu Y, Zhou WC, Luo F, et al. Effects of BN/SiC dual-layer interphase on mechanical and dielectric properties of SiCf/SiC composites. Ceram Int 2014, 40: 3411-3418.

[105] Zhu GX, Dong SM, Ni DW, et al. Microstructure, mechanical properties and oxidation resistance of $\mathrm{SiCf} / \mathrm{SiC}$ composites incorporated with boron nitride nanotubes. RSC Adv 2016, 6: 83482-83492.

[106] Wang JJ, Lin WS, Duan LH, et al. Carbon fiber reinforced $\mathrm{SiC}$ matrix composites fabricated by preceramic impregnation and pyrolysis process combining $\mathrm{SiC}$ nano powder infiltration. $A M R$ 2014, 1052: 34-39.

[107] Liu HT, Tian H. Mechanical and microwave dielectric properties of $\mathrm{SiCf} / \mathrm{SiC}$ composites with $\mathrm{BN}$ interphase prepared by dip-coating process. J Eur Ceram Soc 2012, 32: 2505-2512.

[108] Cai T, Qiu WF, Liu D, et al. Synthesis of ZrC-SiC powders by a preceramic solution route. $J$ Am Ceram Soc 2013, 96: 3023-3026

[109] Galusek D, Klement $\mathrm{R}$, Sedláček $\mathrm{J}$, et al. $\mathrm{Al}_{2} \mathrm{O}_{3}-\mathrm{SiC}$ composites prepared by infiltration of pre-sintered alumina with a poly(allyl)carbosilane. J Eur Ceram Soc 2011, 31: 111-119.

[110] Rocha RM, Bressiani JC, Bressiani AHA. Ceramic substrates of $\beta$-SiC/SiAlON composite from preceramic polymers and Al-Si fillers. Ceram Int 2014, 40: 1392913936.

[111] Wang H, Gao B, Chen XB, et al. Synthesis and pyrolysis of a novel preceramic polymer PZMS from PMS to fabricate high-temperature-resistant $\mathrm{ZrC} / \mathrm{SiC}$ ceramic composite. Appl Organomet Chem 2013, 27: 166-173.

[112] Yamamoto G, Yokomizo K, Omori $\mathrm{M}$, et al. Polycarbosilane-derived SiC/single-walled carbon nanotube nanocomposites. Nanotechnology 2007, 18: 145614.

[113] Windsheimer H, Travitzky N, Hofenauer A, et al. Laminated object manufacturing of preceramic-paper-derived Si-SiC composites. Adv Mater 2007, 19: 4515-4519.
[114] Llorente J, Belmonte M. Friction and wear behaviour of silicon carbide/graphene composites under isooctane lubrication. J Eur Ceram Soc 2018, 38: 3441-3446.

[115] Díaz-Rodríguez P, Gómez-Amoza L, Landin M. The synergistic effect of VEGF and biomorphic silicon carbides topography onin vivoangiogenesis and human bone marrow derived mesenchymal stem cell differentiation. Biomed Mater 2015, 10: 045017.

[116] Gryshkov O, Klyui NI, Temchenko VP, et al. Porous biomorphic silicon carbide ceramics coated with hydroxyapatite as prospective materials for bone implants. Mat Sci Eng C 2016, 68: 143-152.

[117] Will J, Hoppe A, Müller FA, et al. Bioactivation of biomorphous silicon carbide bone implants. Acta Biomater 2010, 6: 4488-4494.

[118] Prakash C, Kansal HK, Pabla BS, et al. Processing and characterization of novel biomimetic nanoporous bioceramic surface on $\beta$-Ti implant by powder mixed electric discharge machining. J Mater Eng Perform 2015, 24: 3622-3633.

[119] Walker LS, Marotto VR, Rafiee MA, et al. Toughening in graphene ceramic composites. ACS Nano 2011, 5: 3182-3190.

[120] Riley FL. Silicon nitride and related materials. $J$ Am Ceram Soc 2004, 83: 245-265.

[121] Fu XL, Zhu N, Peng ZJ. One-step synthesis and characterization of tree-like branched $\alpha-\mathrm{Si}_{3} \mathrm{~N}_{4}$ nano/submicron-structures by pyrolysis of a polymer precursor. Solid State Sci 2012, 14: 1267-1272.

[122] Peng ZJ, Zhu N, Fu XL, et al. Growth and mechanism of network-like branched $\mathrm{Si}_{3} \mathrm{~N}_{4}$ nanostructures. $J$ Am Ceram Soc 2010, 93: 2264-2267.

[123] Zhu N, Peng ZJ, Fu XL, et al. A simple approach to controllably grow network-like branched single-crystalline $\mathrm{Si}_{3} \mathrm{~N}_{4}$ nanostructures. Solid State Sci 2010, 12: 1076-1079.

[124] Jiang YG, Zhang CR, Cao F, et al. Effects of thermal load on mechanical properties and microstructures of $3 \mathrm{D}$ $\mathrm{SiO}_{2} \mathrm{f} / \mathrm{Si}_{3} \mathrm{~N}_{4}-\mathrm{BN}$ composites using polyborosilazane. Mat Sci Eng A 2008, 487: 597-600.

[125] Jiang YG, Zhang CR, Cao F, et al. Fabrication of high performance 2.5D $\quad \mathrm{SiO}_{2} \mathrm{f} / \mathrm{Si}_{3} \mathrm{~N}_{4}$-BN composites for high-temperature application. Adv Eng Mater 2007, 9: 114-116.

[126] Das M, Bhimani K, Balla VK. In vitro tribological and biocompatibility evaluation of sintered silicon nitride. Mater Lett 2018, 212: 130-133.

[127] Bodišová K, Kašiarová M, Domanická M, et al. Porous silicon nitride ceramics designed for bone substitute applications. Ceram Int 2013, 39: 8355-8362.

[128] Pezzotti G, Bock RM, McEntire BJ, et al. In vitro antibacterial activity of oxide and non-oxide bioceramics for arthroplastic devices: I. In situ time-lapse Raman spectroscopy. Analyst 2018, 143: 3708-3721.

[129] Cappi B, Neuss S, Salber J, et al. Cytocompatibility of high strength non-oxide ceramics. J Biomed Mater Res 2010, 93A: 67-76. 
[130] Vallachira Warriam Sasikumar P, Zera E, Graczyk-Zajac M, et al. Structural design of polymer-derived SiOC ceramic aerogels for high-rate $\mathrm{Li}$ ion storage applications. $J \mathrm{Am}$ Ceram Soc 2016, 99: 2977-2983.

[131] Yan XJ, Tsotsis TT, Sahimi M. Fabrication of high-surface area nanoporous $\mathrm{SiOC}$ materials using pre-ceramic polymer blends and a sacrificial template. Microporous Mesoporous Mater 2015, 210: 77-85.

[132] Guo AR, Roso M, Modesti M, et al. Preceramic polymer-derived SiOC fibers by electrospinning. $J$ Appl Polym Sci 2014, 131: 1082-1090.

[133] Vakifahmetoglu C, Colombo P. A direct method for the fabrication of macro-porous $\mathrm{SiOC}$ ceramics from preceramic polymers. Adv Eng Mater 2008, 10: 256-259.

[134] Vakifahmetoglu C, Zeydanli D, de Mello Innocentini MD, et al. Gradient-hierarchic-aligned porosity SiOC ceramics. Sci Rep 2017, 7: 41049.

[135] Takahashi T, Münstedt H, Modesti M, et al. Oxidation resistant ceramic foam from a silicone preceramic polymer/polyurethane blend. J Eur Ceram Soc 2001, 21: 2821-2828.

[136] Colombo P. Macro- and micro-cellular porous ceramics from preceramic polymers. Compos Sci Technol 2003, 63: 2353-2359.

[137] Colombo P, Arcaro A, Francesconi A, et al. Effect of hypervelocity impact on microcellular ceramic foams from a preceramic polymer. Adv Eng Mater 2003, 5: 802-805.

[138] Colombo P. Cellular ceramics with hierarchical porosity from preceramic polymers. IOP Conf Ser: Mater Sci Eng 2011, 18: 012002.

[139] Yuan XY, Jin HL, Yan XB, et al. Synthesis of ordered mesoporous silicon oxycarbide monoliths via preceramic polymer nanocasting. Microporous Mesoporous Mater 2012, 147: 252-258.

[140] Pan JM, Pan JF, Cheng XN, et al. Synthesis of hierarchical porous silicon oxycarbide ceramics from preceramic polymer and wood biomass composites. J Eur Ceram Soc 2014, 34: 249-256.

[141] Pan JM, Ren J, Xie Y, et al. Porous SiOC composites fabricated from preceramic polymers and wood powders for efficient dye adsorption and removal. Res Chem Intermed 2017, 43: 3813-3832.

[142] Hassan MM, Takahashi T, Koyama K. Preparation and characterisation of SiOC ceramics made from a preceramic polymer and rice bran. J Eur Ceram Soc 2013, 33: 1207-1217.

[143] Ma J, Ning YL, Gong CR, et al. Three-dimensionally ordered macroporous (3DOM) SiOC on a cordierite monolith inner wall and its properties for soot combustion. RSC Adv 2015, 5: 53441-53447.

[144] Yan XJ, Sahimi M, Tsotsis TT. Fabrication of high-surface area nanoporous $\mathrm{SiOC}$ ceramics using pre-ceramic polymer precursors and a sacrificial template: Precursor effects. Microporous Mesoporous Mater 2017, 241: 338-345.
[145] Naviroj M, Miller SM, Colombo P, et al. Directionally aligned macroporous $\mathrm{SiOC}$ via freeze casting of preceramic polymers. J Eur Ceram Soc 2015, 35: 2225-2232.

[146] Soltani N, Simon U, Bahrami A, et al. Macroporous polymer-derived $\mathrm{SiO}_{2} / \mathrm{SiOC}$ monoliths freeze-cast from polysiloxane and amorphous silica derived from rice husk. J Eur Ceram Soc 2017, 37: 4809-4820.

[147] Zhuo R, Colombo P, Pantano C, et al. Silicon oxycarbide glasses for blood-contact applications. Acta Biomater 2005, 1: $583-589$.

[148] Grossenbacher J, Gullo MR, Dalcanale F, et al. Cytotoxicity evaluation of polymer-derived ceramics for pacemaker electrode applications. J Biomed Mater Res 2015, 103: 3625-3632.

[149] Tamayo A, Mazo MA, Ruiz-Caro R, et al. Mesoporous silicon oxycarbide materials for controlled drug delivery systems. Chem Eng J 2015, 280: 165-174.

[150] Tamayo A, Mazo MA, Veiga MD, et al. Drug kinetics release from Eudragit - Tenofovir@SiOC tablets. Mat Sci Eng C 2017, 75: 1097-1105.

[151] Tamayo A, Rubio F, Rubio J, et al. Surface and structural modification of nanostructured mesoporous silicon oxycarbide glasses obtained from preceramic hybrids aged in $\mathrm{NH}_{4} \mathrm{OH}$. $J$ Am Ceram Soc 2013, 96: 323-330.

[152] Vakifahmetoglu C, Zeydanli D, Ozalp VC, et al. Hierarchically porous polymer derived ceramics: A promising platform for multidrug delivery systems. Mater Des 2018, 140: 37-44.

[153] Bharadwaj L, Fan Y, Zhang LG, et al. Oxidation behavior of a fully dense polymer-derived amorphous silicon carbonitride ceramic. J Am Ceram Soc 2004, 87: 483-486.

[154] Degenhardt U, Stegner F, Liebscher C, et al. Sintered silicon nitride/nano-silicon carbide materials based on preceramic polymers and ceramic powder. J Eur Ceram Soc 2012, 32: 1893-1899.

[155] Iwamoto Y, Völger W, Kroke E, et al. Crystallization behavior of amorphous silicon carbonitride ceramics derived from organometallic precursors. J Am Ceram Soc 2004, 84: 2170-2178.

[156] Nangrejo MR, Bao XJ, Edirisinghe MJ. Preparation of silicon carbide-silicon nitride composite foams from pre-ceramic polymers. J Eur Ceram Soc 2000, 20: $1777-1785$.

[157] Graczyk-Zajac M, Fasel C, Riedel R. Polymer-derived-SiCN ceramic/graphite composite as anode material with enhanced rate capability for lithium ion batteries. $J$ Power Sources 2011, 196: 6412-6418.

[158] Reinold LM, Graczyk-Zajac M, Gao Y, et al. Carbon-rich $\mathrm{SiCN}$ ceramics as high capacity/high stability anode material for lithium-ion batteries. J Power Sources 2013 , 236: 224-229.

[159] Wilfert J, Meier K, Hahn K, et al. SiCBN composites by spark plasma sintering (SPS) of precursor-derived SiBNC powders. J Ceram Sci Technol 2010, 1: 1-6.

[160] Bernardo E, Colombo P, Hampshire S. SiAlON-based 
ceramics from filled preceramic polymers. $J$ Am Ceram Soc 2006, 89: 3839-3842.

[161] Bernardo E, Colombo P, Pippel E, et al. Novel mullite synthesis based on alumina nanoparticles and a preceramic polymer. J Am Ceram Soc 2006, 89: 1577-1583.

[162] Griggio F, Bernardo E, Colombo P, et al. Kinetic studies of mullite synthesis from alumina nanoparticles and a preceramic polymer. $J$ Am Ceram Soc 2008, 91: 2529-2533.

[163] Schlier L, Fu ZW, Harris J, et al. Crack healing of ferrosilicochromium-filled polymer-derived ceramic composites. J Eur Ceram Soc 2018, 38: 2495-2501.

[164] Bernardo E, Carlotti JF, Dias PM, et al. Novel akermanite-based bioceramics from preceramic polymers and oxide fillers. Ceram Int 2014, 40: 1029-1035.

[165] Elsayed H, Zocca A, Bernardo E, et al. Development of bioactive silicate-based glass-ceramics from preceramic polymer and fillers. J Eur Ceram Soc 2015, 35: 731-739.

[166] Fiocco L, Elsayed H, Daguano JKMF, et al. Silicone resins mixed with active oxide fillers and $\mathrm{Ca}-\mathrm{Mg}$ silicate glass as alternative/integrative precursors for wollastonite-diopside glass-ceramic foams. J Non-Cryst Solids 2015, 416: 44-49.

[167] Fiocco L, Michielsen B, Bernardo E. Silica-bonded apatite scaffolds from calcite-filled preceramic polymers. $J$ Eur Ceram Soc 2016, 36: 3211-3218.

[168] Fiocco L, Li S, Stevens MM, et al. Biocompatibility and bioactivity of porous polymer-derived $\mathrm{Ca}-\mathrm{Mg}$ silicate ceramics. Acta Biomater 2017, 50: 56-67.

[169] Biasetto L, Elsayed H, Bonollo F, et al. Polymer-derived sphene biocoating on cp-Ti substrates for orthopedic and dental implants. Surf Coat Technol 2016, 301: 140-147.

[170] Elsayed H, Zocca A, Franchin G, et al. Hardystonite bioceramics from preceramic polymers. J Eur Ceram Soc 2016, 36: 829-835.

[171] Gao CD, Deng YW, Feng P, et al. Current progress in bioactive ceramic scaffolds for bone repair and regeneration. Int J Mol Sci 2014, 15: 4714-4732.

[172] Wu CT, Fan W, Zhou YH, et al. 3D-printing of highly uniform $\mathrm{CaSiO}_{3}$ ceramic scaffolds: Preparation, characterization and in vivo osteogenesis. J Mater Chem 2012, 22: 12288.

[173] Wang C, Xue Y, Lin KL, et al. The enhancement of bone regeneration by a combination of osteoconductivity and osteostimulation using $\beta-\mathrm{CaSiO}_{3} / \beta-\mathrm{Ca}_{3}\left(\mathrm{PO}_{4}\right)_{2}$ composite bioceramics. Acta Biomater 2012, 8: 350-360.

[174] Bernardo E, Tomasella E, Colombo P. Development of multiphase bioceramics from a filler-containing preceramic polymer. Ceram Int 2009, 35: 1415-1421.

[175] Elsayed H, Colombo P. Crack-free silicate bioceramics from preceramic polymers. Adv Appl Ceram 2016, 115 193-199.

[176] Fiocco L, Bernardo E, Colombo P, et al. Novel processing of bioglass ceramics from silicone resins containing microand nano-sized oxide particle fillers. J Biomed Mater Res Part A 2014, 102: 2502-2510.

[177] Bernardo E, Colombo P, Cacciotti I, et al. Porous wollastonite-hydroxyapatite bioceramics from a preceramic polymer and micro- or nano-sized fillers. J Eur Ceram Soc 2012, 32: 399-408.

[178] Fiocco L, Li S, Bernardo E, et al. Highly porous polymerderived wollastonite-hydroxycarbonate apatite ceramics for bone regeneration. Biomed Mater 2016, 11: 025016.

[179] Fiocco L, Ferroni L, Gardin C, et al. Wollastonite-diopside glass-ceramic foams from supercritical carbon dioxide-assisted extrusion of a silicone resin and inorganic fillers. $J$ Non-Cryst Solids 2016, 443: 33-38.

[180] Fiocco L, Elsayed H, Ferroni L, et al. Bioactive wollastonite-diopside foams from preceramic polymers and reactive oxide fillers. Materials 2015, 8: 2480-2494.

[181] De Castro Juraski A, Rodas ACD, Elsayed H, et al. The in vitro bioactivity, degradation, and cytotoxicity of polymer-derived wollastonite-diopside glass-ceramics. Materials 2017, 10: 425.

[182] Fiocco L, Agnoli S, Pedron D, et al. Wollastonitediopside-carbon composite foams from a silicone resin and inorganic fillers. Ceram Int 2018, 44: 931-937.

[183] Fu SY, Liu W, Liu SW, et al. 3D printed porous $\beta-\mathrm{Ca}_{2} \mathrm{SiO}_{4}$ scaffolds derived from preceramic resin and their physicochemical and biological properties. Sci Technol Adv Mater 2018, 19: 495-506.

[184] Fu S-Y, Yu B, Ding H-F, et al. Zirconia incorporation in 3D printed $\beta-\mathrm{Ca}_{2} \mathrm{SiO}_{4}$ scaffolds on their physicochemical and biological property. J Inorg Mater 2019, 34: 444-454.

Open Access This article is licensed under a Creative Commons Attribution 4.0 International License, which permits use, sharing, adaptation, distribution and reproduction in any medium or format, as long as you give appropriate credit to the original author(s) and the source, provide a link to the Creative Commons licence, and indicate if changes were made.

The images or other third party material in this article are included in the article's Creative Commons licence, unless indicated otherwise in a credit line to the material. If material is not included in the article's Creative Commons licence and your intended use is not permitted by statutory regulation or exceeds the permitted use, you will need to obtain permission directly from the copyright holder.

To view a copy of this licence, visit http://creativecommons.org/licenses/by/4.0/. 